IZA DP No. 8483

Manufacturing Growth and the Lives of Bangladeshi Women

Rachel Heath

A. Mushfiq Mobarak

September 2014 


\title{
Manufacturing Growth and the Lives of Bangladeshi Women
}

\author{
Rachel Heath \\ University of Washington \\ A. Mushfiq Mobarak \\ Yale University \\ and IZA
}

Discussion Paper No. 8483
September 2014

IZA

P.O. Box 7240

53072 Bonn

Germany

Phone: +49-228-3894-0

Fax: +49-228-3894-180

E-mail: iza@iza.org

\begin{abstract}
Any opinions expressed here are those of the author(s) and not those of IZA. Research published in this series may include views on policy, but the institute itself takes no institutional policy positions. The IZA research network is committed to the IZA Guiding Principles of Research Integrity.

The Institute for the Study of Labor (IZA) in Bonn is a local and virtual international research center and a place of communication between science, politics and business. IZA is an independent nonprofit organization supported by Deutsche Post Foundation. The center is associated with the University of Bonn and offers a stimulating research environment through its international network, workshops and conferences, data service, project support, research visits and doctoral program. IZA engages in (i) original and internationally competitive research in all fields of labor economics, (ii) development of policy concepts, and (iii) dissemination of research results and concepts to the interested public.
\end{abstract}

IZA Discussion Papers often represent preliminary work and are circulated to encourage discussion. Citation of such a paper should account for its provisional character. A revised version may be available directly from the author. 


\section{ABSTRACT}

\section{Manufacturing Growth and the Lives of Bangladeshi Women*}

We study the effects of explosive growth in the Bangladeshi ready-made garments industry on the lives on Bangladeshi women. We compare the marriage, childbearing, school enrollment and employment decisions of women who gain greater access to garment sector jobs to women living further away from factories, to years before the factories arrive close to some villages, and to the marriage and enrollment decisions of their male siblings. Girls exposed to the garment sector delay marriage and childbirth. This stems from (a) young girls becoming more likely to be enrolled in school after garment jobs (which reward literacy and numeracy) arrive, and (b) older girls becoming more likely to be employed outside the home in garment-proximate villages. The demand for education generated through manufacturing growth appears to have a much larger effect on female educational attainment compared to a large-scale government conditional cash transfer program to encourage female schooling.

JEL Classification: $\quad$ O12, F16, I25, J23

Keywords: ready-made garment exports, Bangladesh, marriage, fertility, schooling

Corresponding author:

A. Mushfiq Mobarak

Yale School of Management

135 Prospect Street

P.O. Box 208200

New Haven, CT 06520-8200

USA

E-mail: ahmed.mobarak@yale.edu

\footnotetext{
${ }^{*}$ We are grateful for funding from the National Science Foundation Grant SES-0527751. We thank Treb Allen, David Atkin, Priyanka Anand, Mark Klee, Richard Mansfield, Emily Oster, Owen Ozier, Peter Schott, Gil Shapira, Manisha Shah and seminar participants from the University of Connecticut, University of Washington (Jackson School), Yale University, International Growth Centre, and the Northeast Universities Development Consortium Conference for comments. The findings, interpretations and conclusions expressed in this paper are entirely those of the authors, and do not necessarily represent the views of the World Bank, its Executive Directors, or the governments of the countries they represent.
} 


\section{Introduction}

This paper documents the effects of the remarkable and rapid growth of the ready-made garment sector in Bangladesh on the lives of Bangladeshi women. The sector was virtually nonexistent in 1980 (Mostafa and Klepper 2009), but has grown an average of 17\% per year since inception, and now accounts for over 75\% of Bangladesh's export earnings (Bangladesh Export Processing Bureau 2009). The industry currently employs almost 4 million workers in Bangladesh (BGMEA 2013), and was the first to provide employment opportunities to women in large-scale in a country where women traditionally have not worked outside the home. In addition to raising the opportunity cost of being married and having children, attractive manufacturing jobs require basic literacy and numeracy (Amin et al. 1998; Zohir 2001; Paul-Majumder and Begum 2006), and the arrival of garment factories therefore has potentially affected enrollment, employment, marriage and childbearing decisions for Bangladeshi women.

The remarkable growth in this export-oriented sector in Bangladesh is emblematic of the large expansion in low-skill manufacturing jobs around the developing world over the last fifty years (Mammen and Paxson 2000). Manufacturing expansion has often been associated with increases in female labor force participation (Atkin 2009). There is very little rigorous analysis of the welfare effects of access to factory jobs for women, and the 'evidence' is dominated by anecdotes from antisweatshop activists about the negative effects of hazardous working conditions. The evidence gap is especially pertinent for policymaking in Bangladesh, where well-publicized garment factory collapses and fires and their attendant death tolls recently captured the world's attention (New York Times 2013). Both individual large buyers as well as the U.S. government subsequently made moves to restrict or boycott garment exports from Bangladesh (PRI/BBC 2013). It has therefore become imperative to rigorously evaluate the full range of welfare effects of garment factory jobs in 
Bangladesh. Export restrictions and boycotts have the potential to hurt the same workers that they are designed to protect.

Our study fits within the literature on the effects of an export-oriented manufacturing sector on development outcomes (Verhoogen 2008; Atkin 2012; Brambilla et al. 2012). The literature on the causes and consequences of early marriage and childbearing (Jensen and Thornton 2003; Mobarak et al. 2013) is also closely related. Since garment sector jobs reward cognitive skills and thus increase the returns to education, our results also contribute to the role of demand for schooling in determining educational investments. The literature on education in developing countries is heavily tilted in favor of supply-side approaches such as building schools, providing schooling inputs, improving school quality or supplying conditional cash transfers for school attendance. ${ }^{1}$ Understanding the role of demand is important for policy, since it could imply that promoting export-led manufacturing and increasing returns to skill is the more effective path to human capital accumulation (Federman and Levine 2005; Helper et al. 2006; Le Brun et al. 2011).

Our results suggest that the rise of the garment industry can help explain the declining fertility, increasing age at marriage, and rapid increase in girls' educational attainment during this period, both in absolute terms and relative to boys (see Figure 1). ${ }^{2}$ Approximately 80 percent of garment factory workers in Bangladesh are female (Khatun et al. 2007) and extrapolation from our data and national surveys suggest that around fifteen percent of women nationwide between the

\footnotetext{
${ }^{1}$ See, for instance, Burde \& Linden (2013) on building schools, Duflo et al. (2011) on decreasing class size and tracking, Duflo et al. (2012) on rewarding teachers for attendance, Glewwe et al. (2009) on providing textbooks, Banerjee et al. (2007) on remedial education programs, Muralidharan \& Sundararaman (2011) on teacher incentive pay, or Glewwe et al. (2004) on flipcharts. Kremer \& Holla (2009) reviews several evaluations of education sector projects in developing countries.

${ }^{2}$ We stop the enrollment graph in 2000 , since the last year that a nationally representative survey allowed us to construct yearly enrollment was 2005, and the last couple years are noisy. However, the World Development indicators (http://data.worldbank.org/data-catalog/world-development-indicators) collected by the World Bank in most (but not all) years from 2005 to present confirm that girls' enrollment has remained slightly higher than boys' enrollment.
} 
ages of 16 and 30 work in the garment industry. ${ }^{3}$ The education results are particularly policyrelevant, as Bangladesh has surpassed the third Millennium Development Goal of gender equity in enrollments, a goal with which many other countries in Western Asia and sub-Saharan Africa continue to struggle. Our research design permits a study of investments in girls relative to boys, which is of considerable policy (Levine et al. 2009; Chaaban and Cunningham 2011; Gibbs 2011; Girl Up 2011; World Bank 2011a; World Bank 2011b) and also academic interest, given the comparative advantage girls possess in skilled tasks (Pitt et al. 2012). Our results provide one hitherto unexplored explanation for the accelerated gender equity in education in Bangladesh, thus generating important policy implications for other developing countries interested in emulating Bangladesh's success.

In theory, access to factory jobs can alter women's school, work, marriage and childbearing decisions through a few different mechanisms. As documented for maquiladora jobs in Mexico, older children may be induced to drop out of school to access the factory jobs (Atkin 2012). Conversely, younger children (who are still too young for the factory jobs and do not face the temptation to drop out and begin earning immediately) may respond by investing in education if the availability of relatively well-paid manufacturing jobs increase the returns to education. Educational attainment might also increase through a wealth effect, if parents can now better afford to send their children to school. Both the increased enrollment channel and the direct factory employment effects would result in girls delaying marriage and childbirth.

\footnotetext{
${ }^{3}$ Specifically, there are 4 million garment workers nationwide, an estimated 80 percent of whom are female (Khatun et al 2007; BGMEA 2013). We assume that 90 percent of these female workers are between the ages of 16 and 30 , which is consistent with the age distribution in our sampled female workers, yielding an estimate of 2.88 million female garment workers nationwide between the ages of 16 and 30. According to the nationally representative 2005 Household Income and Expenditure survey, 25 percent of females nationwide are between ages 16 and 30. So based on the UN's estimate of 155 million total population in 2012 , there are 18.5 million women between the ages of 16 and 30 , and $2.88 / 18.5 \approx 15$ percent of them work in the garment industry.
} 
We begin by examining the effects of access to factory jobs on girls' marriage and childbearing decisions, given the clearest predictions on these outcomes, and their immediate and close link to women's welfare. We identify the effects of the garment sector on marriage and childbirth using retrospective data on these outcomes from 1395 households in 60 Bangladeshi villages that vary with respect to whether the villages are within commuting distance of garment factories, and the date on which the first factories were opened close to each village. We estimate discrete time hazard models for the age at marriage and age at first birth for girls with greater lifetime exposure to factory jobs, controlling for both persistent differences between garment-proximate and control villages, and differential time trends in garment-proximate villages. We document that the hazard of marriage and childbirth at early ages (12-18) drops sharply for girls when they gained exposure to the readymade garment sector. This is important because other research has documented large negative welfare implications of early marriage and early childbirth (Geronimus and Korenman 1992; Ribar 1994; Jensen and Thornton 2003; Hotz et al. 2005; Fletcher and Wolfe 2009; Ashcraft et al. 2013).

Next we explore the mechanisms by which these delays in marriage and childbirth occur. Did girls increase their educational attainment in order to obtain well-paying garment jobs which require numeracy and literacy, which then led to a postponement of marriage due to greater educational attainment? We assess the effect of cumulative years of exposure to garment factory jobs on the total years of educational attainment (for those with completed schooling histories), adding an additional comparison to the girls' male siblings, given that garment production is has been a much larger innovation in the labor market for girls than for boys (Amin et al. 1998; Kabeer and Mahmud 2004). We find that girls gain an extra 1.5 years of education relative to their brothers in the median garment-proximate village. This represents a 50\% increase in girls' educational attainment over control villages that do not have a garment factory nearby. We observe the increase in female 
education (relative to their male siblings) even in families where the mother or older sister never worked in a factory, which suggests that increased demand for skills in factories that offer job opportunities for women is a likely channel through which the enrollment gains are realized, in addition to any family wealth effect or changes in intra-household time allocation from other household members working in garment factories.

We next use retrospective data on the entire history of annual school enrollment decisions for each girl to test whether the effects of the garment industry on schooling are strongest for younger girls. We find that young girls (aged 5-9) are more likely to stay enrolled in school when factories open close to their village compared to girls in comparison villages in the same sub-district that are not located within commuting distance of factories, relative to earlier years (before the factory opens), and relative to male siblings of the same age.

These education results contribute to the recent literature on education demand in developing countries which studies the effects of changing the perceptions of the returns to education through informational interventions. ${ }^{4}$ Other studies have examined schooling decisions after the returns to specific types of skills improved in India, such as farmer comprehension of new agricultural technologies (Foster and Rosenzweig 1996; Badiani 2009), or English language skills that improve access to IT service jobs (Munshi and Rosenzweig 2006; Shastry 2011; Oster and Steinberg 2013). We complement this literature by providing estimates in a different country where the returns to education improved because manufacturing growth led to a greater demand for basic, generalist skills like literacy and numeracy.

Our data also indicate that the delays in marriage and childbirth we estimate likely also stem from girls in garments-proximate villages choosing to work in factories when they are about 17-23

\footnotetext{
${ }^{4}$ Jensen (2010), Jensen (2012), Nguyen (2008), and Dinkelman and Martinez (2014) conduct randomized controlled trials aimed at changing parents' and children's perceptions of the returns to schooling.
} 
years old, instead of getting married (or staying in school). Factory job access has a small negative effect on school enrollment of 17-18 year olds (unlike the positive effect for younger girls). More importantly, girls who are exposed to factory jobs when they are between 10 and 23 years old (which is the critical age group at risk for early marriage in Bangladesh) are 17 percentage points more likely to have done wage work outside the home, and this is a $79 \%$ increase over the control group.

In summary, access to factory jobs significantly lowers the risk of early marriage and childbirth for girls in Bangladesh, and this is due to both the girls postponing marriage to work in factories, and the girls staying in school at earlier ages. We benchmark the magnitude of the effects of the garment industry against the effects of a large-scale (US\$15 million per year) conditional cash transfer for schooling intervention run by the Bangladesh government with multilateral donor support. The program has paid for 2 million girls to remain in school, conditional on remaining unmarried. The dramatic improvement in girls' outcomes in Bangladesh in the past 30 years has frequently but casually been attributed to the FSP, ${ }^{5}$ but our estimates suggest that the rapid expansion of the garment sector has been a much more important reason for the decreases in earlier marriages and fertility and the closing of the gender enrollment gap in Bangladesh.

The rest of the paper proceeds as follows. Section 2 provides background on the garment industry's relationship with girls' schooling, work and marriage decisions. In section 3 we describe our empirical strategy. Section 4 gives results, and section 5 concludes.

\section{Background on the Garment Industry}

\footnotetext{
${ }^{5}$ For instance, the International Development Association (International Development Association 2009) posted a write-up on its website entitled "Stipends Triple Girls Access to School", in which all of the increase in girls' enrollment between 1991 and 2005 was attributed to the stipend. Since it did not have the data to estimate the counterfactual rise in girls' enrollment absent the program, it was not able to substantiate the claimed effect size. A World Bank internal report writes "There is no systematic evaluation that shows the causal effect of the program on increased enrolment of girls in schools, yet nothing else can explain the exponential increase in gender parity." See also Raynor and Wesson (2006) for a review of other potential effects attributed to the FSP.
} 
As shown in Figure 2, the Bangladeshi garment industry has experienced explosive growth in the past 30 years. In 1983 there were 40,000 people employed in the industry; since then an average yearly growth rate of 17 percent has resulted in a current employment of about 4 million (BGMEA 2013). In fiscal year 2008-09, it accounted for 79\% of exports and 14\% of Bangladeshi GDP (Bangladesh Bureau of Statistics 2010). Moreover, according to expert projections, this growth is expected to continue in the near future. Based on surveys of a large number of chief purchasing officers (CPOs) of European and US apparel buyers, McKinsey \& Company (2011) report that CPOs plan to shift apparel sourcing away from China in the coming years due to increasing wage bills and labor shortages, and Bangladesh is cited as the next biggest sourcing hot-spot. The report projects that Bangladesh's apparel exports will double by 2015, and triple by 2021, leading to a labor demand of 3.5 million additional workers by 2020 .

Recent high-profile factory disasters, such as the tragic building collapse in April 2013 that killed 1127 workers, raises important questions about both worker safety and the risk to growth in this sector. The disasters were well covered by the international media, and captured the world's attention (New York Times 2013). The coverage led to calls for boycotts or other restrictions on Bangladeshi exports. A rigorous evaluation of the welfare effects of factory jobs for Bangladeshi women is necessary to understand the potential economic implications of such actions. If access to factory jobs allows women to delay marriage and childbirth, and to invest in education, then there may be adverse unintended consequences of boycotts or restrictions on the very population that these policies are intended to help.

There are several channels through which the arrival of garment jobs could change young women's lives. Firstly, the garment industry overwhelmingly hires young women, who would otherwise be beginning marriage and childbirth or finishing their education. Figure 3 shows the age 
distribution of the female garment workers in our 2009 survey. The middle 50 percent are between the ages of 19 and 28. Moreover, the fact that 20 percent of female workers are age 18 or younger suggests that teenagers do choose between beginning garment work, finishing their education, and early marriage and childbearing. While being married or having a child does not automatically disqualify a woman from garment employment, the long hours and frequent overtime of garment factories are difficult to combine with or home or child care responsibilities. ${ }^{6}$

The garment industry could also affect school enrollment decisions; better jobs within factories reward education. Figure 3 also displays the distribution of educational attainment of female garment workers. While twenty percent of workers have no education, more than half (62 percent) have five or more years of education. Table 1 compares these garment workers to others in the sampled villages (broken down by garment-proximate villages and non-garment villages), and confirms that garment workers have on average have more education ( 6.0 years) than others in the same villages (4.1 years) or in non-garment villages (3.2 years); each group was approximately the same average age.

Both qualitative evidence and results from our data suggest that garments workers indeed are rewarded for these higher levels of education. While strict threshold requirements for education or other qualifications are rare, managers prefer educated workers who are better at tasks like keeping records or learning new work from a pattern (rather than from watching it be done) which allows them to fill in for absent workers. Indeed, some factories administer English or arithmetic tests to job applicants (Amin et al. 1998). Furthermore, education is even more important in the best garment jobs, including supervisory roles (Paul-Majumder and Begum 2006) and factories in the Export Processing Zone (Zohir 2001), which tend to be highly desirable garment sector jobs with

\footnotetext{
${ }^{6}$ While a few factories with progressive reputations provide day care centers, these factories are the minority.
} 
good working conditions and some benefits such as health care. In all positions, production takes place in teams (Heath 2011), and therefore requires effective communication and coordination across individuals.

Since education is rewarded in garment factories, when a new job arrives, if parents assume it will persist, they may choose to keep their pre-working age children in school with the hopes that their daughters will later be able to secure a better garment factory job. Afsar (1998) argues that nationwide parents - particularly of girls - respond to the returns to education in the garment industry: "both urban and rural poor educate their girl children with an intention to engage them in the garment industry." (cited in Paul-Majumder and Begum 2006, p. 7). At a descriptive level, our data on garment workers does show a positive correlation between education and wages: In a simple Mincer wage regression controlling for age and experience, wages are 3.7\% higher for each extra year of education. This does not necessarily imply a causal effect of education given standard identification concerns, but parents may respond to this observed correlation in their educational investment choices. Moreover, consistent with reports of factories administering literacy tests to potential workers (Amin et al. 1998), education appears to affect potential workers' ability to secure a garment job: controlling for age, an additional year of education is associated with a $2.1 \%$ increase in the probability that a worker works in the garment industry.

\section{Empirical Strategy}

\subsection{Data}

The data in the survey come from a survey of 1395 households conducted by the authors in sixty villages in four sub-districts of Bangladesh: Savar and Dhamrai in Dhaka District; Gazipur Sadar and Kaliakur in Gazipur district. These villages are in a peri-urban area outside of Dhaka city; 
they are cohesive villages with well-defined borders but have influenced by the spread of the garment industry and widening borders of Dhaka. Further details on the sampling and survey can be found in the appendix and in Heath (2011).

In August and September 2009, we gathered information about each member of the sampled households, as well as the schooling, marriage, and childbearing histories of all offspring of the household head and spouse. We collected information regardless of whether the offspring was still in the household, allowing us to avoid concerns about selective out-migration. Specifically, we know the age that the offspring began schooling, timing and length of any interruptions in schooling, and eventual years of completed education. These data allow us to construct a binary variable for whether a child was enrolled in school in a given year, from ages 5 to 18 . We also obtained the labor force participation rates of female offspring.

At the time of the 2009 survey, a garment manufacturer's association official categorized 44 of our villages as within commuting distance of a garment factory (we call these garment-proximate villages) and 16 as not within commuting distance (we call these non-garment villages). This classification was confirmed with the household survey data: $39 \%$ of women ages 16 to 30 in garment-proximate villages work in garment factories, versus $2 \%$ of women of the same age in our sample of control villages. Since garment factories are not placed randomly, it is important to acknowledge the pre-treatment differences between garment-proximate villages and non-garment villages. Table 2 provides summary statistics of some differences between garment-proximate and non-garment villages before the takeoff of the garment industry in the early 1980's. The garmentproximate villages are on average $1.8 \mathrm{~km}$ away from Dhaka, versus an average distance of $6.8 \mathrm{~km}$ for non-garment villages. There are also differences in educational attainment of adults over 50 (who would have finished school before the garment industry began), though they are stronger for males. 
Specifically, males over 50 in garment-proximate villages have an average of 3.48 years of schooling (vs. 1.94 in non-garment villages), while females in garment-proximate villages have an average of 0.82 years of schooling (vs. 0.54 in non-garment villages).

Table 1 illustrates a compositional difference between the factories near the villages in our survey area and the nationwide garment industry. There are a greater number of woven factories in our survey than the garment industry nationwide, which has a greater relative percentage of knitwear factories. Woven factories have greater relative demand for male labor than knitwear factories, because physical strength is required to operate looms. Indeed, $55 \%$ of the garment workers in our sample are female, compared to national estimates that the garment industry is $80 \%$ female (BGMEA 2013). However, woven factories still hire female seamstresses to work on the operating lines, and these jobs are very similar to the jobs in knitwear factories. Accordingly, we argue that girls in our study villages have been affected by the garment industry in a very similar way to girls nationwide. And while it is theoretically possible that we could see effects on boys who anticipate working in woven factories, the garment industry was still a bigger innovation in the labor market for girls than for boys. For instance, 41 percent of males in garment-proximate villages who work outside the home do so in garment factories, compared to 82 percent of females.

To allow for more precise knowledge of a surveyed individual's exposure to the garment industry, we revisited each village in the survey in March 2014 to collect supplemental data on the dates on which garment factories opened in proximity to our sample villages. In each village in the sample, we identified a local person knowledgeable about the history of the village and the timing of the expansion of the garment industry. We asked him/her the first year that people from the village began working in the garment industry, regardless of whether the factory is currently still operating (i.e., including factories that may have already closed down at the time of our survey). We use these 
reports, rather than the inception dates of the factories still in operation, in order to avoid any selection biases associated with factories that have closed down. We combine this survey with the household-level retrospective data to construct measures of an individual's lifetime years of exposure to the garment industry, as well as a binary variable that captures whether there was a garment factory within commuting distance of an individual in any given year.

\subsection{Overview of Identification Strategy}

We use these time-varying measures of an individual's exposure to the garment industry to estimate effects of the garment industry on women's lives. Since garment-proximate villages are different from non-garment villages (as seen in table 2 and discussed in table 3), and the effects of these disparities may vary by gender, we allow both for gender-specific time-invariant differences between garment-proximate villages and non-garment villages and for gender-specific time trends within garment-proximate villages. We can thus be confident that our results are not driven by selection of garment factories into villages based on time-invariant characteristics, or the fact that garment-proximate villages are changing over time relative to non-garment villages. For our education results, we use boys as a further control group for girls, so that we have three sources of identifying variation: (a) girls in villages in the same sub-districts that are further away from factories, (b) earlier years (before any factory arrives close to that village), and (c) the girls' male siblings.

Our measures of access to garment sector jobs assume that exposure to the sector is localized: that effects of the garment industry are concentrated on girls growing up in villages within commuting distance of garment factories. The assumption is reasonable in Bangladesh, where social convention dictates that a girl remain in her parents' house until marriage. Girls and their parents therefore feel much more comfortable if the girl remains at home while working in the garment factory. Some female garment workers do leave their parents' home and live in dormitories or with 
relatives in order to work in a factory far from home, but this is relatively rare and carries a much larger social cost. Garment exposure is also likely localized because girls living in villages where no one works in the garment industry may not know much about the existence of or the requirements for these jobs. Oster and Steinberg (2013) found evidence of such limited spread of information in the context of call center jobs in India.

After controlling for overall and garment-village specific trends in girls' outcomes, two remaining identification concerns are reverse causality and a potential omitted variable correlated with both the dependent variables (girls' schooling or marriage and childbearing decisions) and the arrival of garment jobs. Interviews we conducted with factory owners suggest that reverse causality is unlikely to be a major concern. They reported that the two most common reasons for choosing a location are proximity to roads and infrastructure, and the convenience of using buildings already owned by the factory owner or his family members. Imperfections in land and property markets in Bangladesh due to a weak institutional environment illustrate the economic rationale behind these considerations. There is clear agglomeration in factory locations over time, and initial location choices for the first set of factories are therefore potentially important. We include indicators for a garment-proximate village and its interaction with a female dummy in our estimating equations to control for such baseline differences. Furthermore, we will show below that the (pre-) trends in our main outcome variables are parallel across garment-proximate and non-garment villages.

A remaining concern is the presence of omitted variables correlated with the arrival of garment factories, such as new roads built in the areas closer to Dhaka where garment factories are located. We argue that several facets of our results make it unlikely that such as omitted factor could be explaining them, as a whole. For one, we only see effects on girls' marriage and childbearing outcomes, and not boys. This makes it unlikely that the results are driven any investments in those 
factory-proximate locations that would have changed the marriage market as a whole, or changed the cost of having children. Similarly, we see much stronger effects on girls' schooling than boys, so any infrastructure investment complementary to garment factories would need to be gender-specific. The fact that we see the largest results in younger girls also argues against such a story, since children in Bangladesh typically have to travel further for secondary school than primary school. While individually, each result could be related to a specific omitted variable, it is more difficult to imagine an omitted variable that can explain the entire sets of results on girls and boys.

\subsection{Marriage and Childbearing}

We use data on the timing of marriage and first birth to use discrete time hazard models to estimate the probability that a girl enters marriage or first gives birth in a year as a function of her years of exposure to garment jobs. Our independent variable of interest, GarmentVillage ${ }_{v} x$ YearsExposure $_{\text {w }}$ is equal to the girl's total years of exposure over her life, from birth to the year of each observation $(t){ }^{7}$ Our choice of a cumulative measure of exposure captures the overall effects of the garment industry through both the labor force participation channel (where contemporaneous access matters) and the education channel (where exposure over the whole life matters). ${ }^{8}$ We allow for changing marriage and childbearing rates over time with year fixed effects, and for genderspecific linear enrollment trends in garment-proximate villages. So for girl $i$ in village $v$ in year $t$.

$$
\begin{aligned}
& 1 \text { Married }_{i v t}=\delta \text { GarmentVillage }_{v} \times \text { YearsExposure }_{i v t}+\gamma_{1} \text { GarmentVillage }_{v}+\gamma_{2} \text { GarmentVillage }_{v} \times \\
& \text { Year }+\beta \text { Age }_{i v t}+\lambda_{t}+\varepsilon_{i v t}
\end{aligned}
$$

\footnotetext{
${ }^{7}$ Years Exposure $_{i v t}$ is zero by construction for individuals in non-garment villages, so we cannot include a separate term for its main effect. We write our independent variable as the interaction of exposure with GarmentVillage ${ }_{v}$ to emphasize that within garment-proximate villages, there is variation in exposure to garment jobs based on the village-specific timing of the expansion of the garment industry.

${ }^{8}$ Furthermore, the garment sector provides high wage returns to experience (Heath 2011). The history of exposure affects current salary, and therefore the current opportunity cost of marriage and childbearing. This is yet another reason why lifetime exposure to the sector is the correct RHS variable of interest.
} 
where 1 (Married) $)_{i v t}$ is an indicator for girl $i$ in village $v$ being married by year $t .{ }^{9}$ We also replace the indicator for marriage with an indicator for the girl bearing her first child: 1(FirstBirth) ivt $_{\text {and }}$ estimate the same regression. The coefficient $\delta$ gives the effects of an additional year of exposure to garments job on the probability that a girl gets married or begins childbearing in a given year. We also estimate the same equation using the sample of boys, both to compare to the effects we estimate for girls, and because boys may be indirectly affected through the marriage market choices made by girls in response to the expansion of factories.

\subsection{Educational Attainment}

We examine the impact of the garment industry on girls' educational attainment by considering the effects of the same measure of garment exposure, GarmentVillage ${ }_{v} \times$ Years Exposure $_{i v p}$ on the years of education completed by boys and girls. We allow for increasing educational attainment over time (and the national closing of the gender education gap pictured in Figure 1) with quadratic gender-specific year of birth trends, and again allow for differential trends by year of birth in garment villages, by gender. Sibling fixed effects alleviate any potential concerns over changing compositions of parents in garment villages over time. For child $i$ in family $f$ in village $v$ :

$$
\begin{aligned}
& \text { Education }_{i v f}=\delta_{1} \text { GarmentVillage }_{v} \times \text { YearsExposure }_{i v p}+\delta_{2} \text { GarmentVillage }_{v} \times \text { YearsExposure }_{i v f} \times \\
& \text { Female }_{i v f}+\gamma_{1} \text { GarmentVillage }_{i f f} \times \text { Female }_{i v f}+\gamma_{2} \text { GarmentVillage }_{i v f} \times \text { YearofBirth }_{i v f}+\gamma_{3} \\
& \text { GarmentVillage }_{i v f} \times \text { YearofBirth }_{i v f} \times \text { Female }_{i v f}+\lambda_{1} \text { YearofBirth }_{i v f}+\lambda_{2} \text { YearofBirth }_{i v f}+\lambda_{3} \text { Female }_{i v f} x \\
& \text { YearofBirth }_{i v f}+\lambda_{4} \text { Female }_{i v f} \times \text { YearofBirth }_{i v f}+\theta_{f}+\varepsilon_{i v f}
\end{aligned}
$$

The estimated $\delta_{2}$ gives the effects of the garment industry on girls in garment-proximate villages relative to their brothers, and the sum of $\delta_{1}$ and $\delta_{2}$ compares girls in garment-proximate village to girls in non-garment villages.

\footnotetext{
${ }^{9}$ Divorce is very rare in this context, which makes marriage in year $\mathrm{t}$, and marriage by year $t$ virtually identical.
} 


\subsection{Enrollment}

To estimate whether the effects of access to garment sector jobs on schooling decisions vary across age groups, we use retrospective schooling histories to estimate the relationship between garment jobs and the probability that a girl between the ages of 5 and 18 is enrolled in school in a particular year. Specifically, we test whether enrollment is higher overall for girls relative to boys, in villages proximate to garment factories after the factories opened, using the interaction GarmentVillage $_{v} \times$ PostGarments $_{\text {ifft. }}$ The variable PostGarments ivft $_{\text {is }}$ a binary variable equal to one in years after garment factories started operations within commuting distance of that child's village. We allow enrollment rates to change over time in a flexible way, using gender-specific year fixed effects. We again include gender-specific linear enrollment trends in garment-proximate villages, and sibling fixed effects. We estimate for girl $i$ in family $f$ in village $v$ in year $t$.

$$
\begin{aligned}
& \text { Enroll }_{\text {ifft }}=\delta_{1} \text { GarmentVillage }_{v} \times \text { PostGarments }_{\text {ivft }}+\delta_{2} \text { GarmentVillage }_{v} \times \text { PostGarments }_{\text {ifft }} \times \text { Female }_{\text {ivft }}+ \\
& \delta_{3} \text { GarmentVillage }_{v} \times \text { PostGarments }_{\text {ifft }} \times \text { Age }_{\text {ivft }}+\delta_{4} \text { GarmentVillage }_{v} \times \text { PostGarments }_{\text {ivft }} \times \text { Female }_{\text {ifft }} \times \\
& \text { Age }_{\text {ivft }}+\gamma_{1} \text { GarmentVillage }_{i f f} \times \text { Female }_{i f f t}+\gamma_{2} \text { GarmentVillage }_{i f f} \times \text { Year }+\gamma_{3} \text { GarmentVillage }_{i f f} \times \text { Year } \\
& x \text { Female }_{\text {ivft }}+\beta_{1} \text { Age }_{\text {ivft }}+\beta_{2} \text { Age }_{\text {ivft }} \times \text { Female }_{\text {ivft }}+\lambda_{t}+\lambda_{t} \times \text { Female }_{i v f t}+\theta_{f}+\varepsilon_{\text {ivft }}
\end{aligned}
$$

$\delta_{2}$ provides an estimate of the effect of factory presence on a young girl's enrollment decision relative to her brother's. The sum of $\delta_{1}$ and $\delta_{2}$ compares enrollment of young girls in garmentproximate villages to girls in non-garment villages. We further add interactions with age so that $\delta_{4}$, and $\left(\delta_{3}+\delta_{4}\right)$, respectively, provide estimates for how these two enrollment effects (relative to brothers, and relative to girls in non-garment villages) vary with age.

\subsection{Female Labor Force Participation}

Finally, we estimate whether exposure to garment jobs indeed induced more girls to work outside of the home. We estimate difference-in-difference equations that test whether labor force participation is differentially higher among girls in garment-proximate villages who were exposed to garment jobs 
when they were at critical ages associated with the highest risk for either joining the labor force or getting married. We denote those critical periods with subscript (t0-t1) and estimate for girl $i$ in village $v$ :

$$
1\left(\text { Ever Worked }_{i v}=\delta \text { GarmentVillage }_{v} \times \text { GarmentExposure }_{i v(t 0-t)}+\gamma \text { GarmentVillage }_{v}+\varepsilon_{\text {ivft }}\right.
$$

The coefficient $\delta$ gives the additional probability of working that a girl exposed to an additional year of garment jobs has, compared to a girl in a garment-proximate village with less exposure. ${ }^{10}$

\section{Results}

\subsection{Effects of Garment Jobs on Marriage and Childbearing Decisions}

Table 3 reports the results of discrete time hazard models that examine the effects of years of exposure to garment factories (up to a certain year) on the hazard of a girl getting married by that year, or the hazard of the girl bearing her first child by that year. We use this analysis to explore whether access to factory jobs prompt Bangladeshi women to delay marriage and childbearing, which are important indicators of welfare for females in developing countries (Field and Ambrus 2008). Exposure is defined as the number of years a girl has lived in a village within commuting distance of garment factories since the first factory opened near that village. Only the coefficients of interest are shown in the table; coefficients on all control variables (e.g. the garment-proximate village indicator and year of birth trends) are omitted.

The first column indicates that girls living in garment-proximate villages where factories have been operating for 6.4 years (which is the average exposure in the garment-proximate villages across

\footnotetext{
10 We did not collect data on labor force participation for boys, and therefore cannot use boys as a control group, unlike the educational attainment and enrollment regressions.
} 
all units of observation in the regression) have a $(6.4 \times 0.00048)=0.3$ percentage point lower probability of getting married by that year relative to girls living in control villages in the same district that are not within commuting distance to garment factories. The probability that a girl in our sample is married during the average sample year is $1.1 \%$, and the 0.3 percentage point decrease therefore represents a $28 \%$ decrease in the hazard of getting married. Exposure to the garment sector therefore has a quantitatively large effect on marriage postponement.

The second column explores whether this marriage postponement effect varies by age by adding interaction terms between the measure of garment exposure by a given year, and the girl's age in that year. Figure 4 plots the marginal effects from this estimated regression, and identifies that precise ages at which the marriage postponement occurs. The figure shows that garment sector exposure has large, statistically significant effects on marriage postponement when girls are aged 1218. The effect size is largest at the youngest ages, where early marriage is likely to be the most harmful to girls' development. Given the pre-existing results from the literature on the detrimental effects of early marriage, this result suggests that the rapid expansion of the garment sector in Bangladesh resulted in large welfare gains for women. The fact that the effects are large at the youngest ages provides a hint that the marriage postponement may be related to girls staying enrolled in school, rather than a direct effect of those girls staying unmarried to work in factories. Girls as young as 12-14 typically do not work in factories in Bangladesh, ${ }^{11}$ given the large profit risks faced by American and European retailers who are accused of procuring from factories that employ child labor.

Next we turn our attention from the hazard of early marriage to the hazard of early

\footnotetext{
11 The official minimum age of employment in garment factories is 14 . While factories cannot typically verify employees' ages - so that there's no discrete jump in employment at exactly age 14 -- much of the bad publicity of employing child labor comes from unofficial reports or pictures. The risk of these events is decreasing in the child's age.
} 
childbearing. Column 3 shows that girls living in garment-proximate villages with 6.4 years of factory exposure are $(6.4 \times 0.00036)=0.23$ percentage points less likely to have given birth by that year compared to girls living in control villages in the same district that are not within commuting distance to garment factories. The probability that a girl in our sample has her first child during the average sample year is $0.8 \%$, and the 0.23 percentage point decrease therefore represents a $29 \%$ decrease in the hazard of childbirth. Exposure to the garment sector therefore also results in a quantitatively large effect on postponing childbirth. The fourth column explores the variation in this effect across age groups using interactions between garment exposure and age and age-squared, but the associated plot of marginal effects in Figure 4 does not uncover any clear age patterns. The large standard errors suggest that we are under-powered to detect the age distribution of the garment sector effect on childbirth timing.

The last two columns of Table 3 show that the garment sector had no effect on the marriage or first-birth timing for boys. The estimates are statistically indistinguishable from zero, and the coefficient estimates are 4-5 times smaller in magnitude compared to the girl sample.

We identify the effects of the garment sector on marriage and childbearing using variation between girls living in garment-proximate villages to girls living in control villages in the same subdistricts that are not within commuting distance of any factory. In Table 2 we showed that garmentproximate villages are systematically different from the control villages in a couple of dimensions. This raises a concern that the marriage trends for girls in control villages are not a good counterfactual for the marriage trends in garment-proximate villages. Given our identification strategy that exploits variation in the date of factory arrival, it is important to determine whether the pre-trends in marriage, childbearing and other relevant outcomes (such as school enrollment) before the factories arrive, are parallel across the control and garment-proximate villages. Table 4 estimates 
these pre-trends, and fails to reject that there is no difference in the trends in marriage, childbirth and enrollment before factories arrive across the two sets of villages. Not only is there no statistically significant difference in trend, but the estimated difference in marriage and childbirth trends are an order of magnitude smaller that the effect of garment expansion on marriage/childbirth decisions that we estimate in Table 3. These results suggest that the parallel trends assumption that is crucial for proper statistical inference holds in our context.

In summary, we find that access to factory jobs allows young girls in Bangladesh to delay both marriage and childbearing in statistically and quantitatively significant way. These results could be explained by families choosing to postpone their daughter's marriage and childbirth so that either (a) she can to work in factories, or (b) she can invest in schooling at an early age to have a better shot at high-paid garment sector work later in life, or (c) because the adults in the household now have better paid factory jobs, and the family is wealthier and can afford to invest in child quality, and keep young girls in school rather than marry them off. We will explore these potential mechanisms in the next few sub-sections by studying the effects of garment sector expansion on school enrollment, educational attainment and factory work. The marriage postponement effects we estimate above are largest among the youngest girls (aged 12-15), which provides a strong hint that the delay might be related to educational investments, in addition to any direct effect of girls working in factories. We therefore study the enrollment and education effects first.

\subsection{The Effects of Garment Jobs on Education Attainment and School Enrollment}

Table 5 provides estimates of the effects of exposure to garment jobs on educational attainment. An additional year of exposure to garment jobs leads to a statistically significant increase 
of 0.26 years of education for boys and an additional 0.22 years effect on girls. ${ }^{12}$ At the average value of years of garment exposure in this regression (6.8 years) ${ }^{13}$ this estimate implies the gender gap in educational attainment closes by 1.5 years due to the presence of garment factories. Garment workers have 2.8 years more education on average than residents of non-garment villages (see table 1), and so the magnitude of the regression estimate appears plausible.

These results are generated using the whole sample of offspring of the household head, which may include some children who are still in school and for whom we do not observe a completed education history. In the next two columns we re-assess the effects of garment jobs on educational attainment, but concentrate on the sample of older offspring who are likely to have completed their schooling. Specifically, we re-estimate the equation for the subsample of children born in 1990 or before (aged 19 or older in 2009), and those born in 1995 or before (aged 14 or older in 2009). We still see positive effects of the garment industry on girls in this sample, relative to their brothers, although the effects are smaller in magnitude: for instance, the estimate in the second column suggests that at the mean value for years of garment exposure for the older sample (5.4 years), the gender gap in educational attainment closed by 0.92 years among children born 1995 or before. As we will see in table 6, the school enrollment effects are largest among the youngest children, and omitting them from the sample is the likely cause of the decrease in magnitude.

The increase in girls' educational attainment may stem from garment factories enhancing the

\footnotetext{
${ }^{12}$ The sum of the two coefficients signifies that each year of garment exposure leads to an additional 0.48 years of completed education for girls in garment-proximate villages relative to control villages within the same sub-district. However, this summed result should be interpreted with greater caution, because our identification strategy provides a more credible estimate for the gender gap in educational attainment, not the absolute value of attainment for girls.

${ }^{13}$ This figure is slightly larger than the average exposure ( 6.4 years) in the marriage and childbearing regressions since the educational attainment regressions have one observation per child. By contrast, in the hazard models for marriage and childbearing, an older unmarried individual will contribute more observations than a younger, unmarried individual. The marriage and childbearing regressions thus yield a sample that is on average slightly older and thus less exposed than the educational attainment regressions.
} 
perceived and actual market returns to skill, thereby creating greater demand for schooling. It could also stem from a wealth effect, whereby mothers or older sisters gained employment at higher wages in garment factories and could now afford to send children to school. Garment jobs may have also increased female bargaining power within households, either for women who took the jobs (Atkin 2009) or for all women given their expanded opportunity set (Majlesi 2014). The increased bargaining power could result in more schooling for girls, if women have a stronger preference for educating their daughters than men do. Finally, a mother or older sister taking a garment job could cause a reallocation of the time use of all household members. These effects could either increase girls' schooling, if families enroll younger children in school as a form of "day care" while mothers or older sisters work, or decrease girls' schooling, if families pull girls out of school to do household chores formerly conducted by the new garment worker.

While it is difficult to identify precisely the exact channels through which the garment industry increases girls' schooling, we provide suggestive evidence that the results are unlikely to be driven entirely by wealth or time allocation effects. We do this by estimating the education attainment equations separately for families where mothers or older sisters worked outside the home (and whose children are therefore more likely to have benefited from the wealth effect or been affected by a reallocation of home duties), and families where mothers or older sisters were not working outside the home. While these families may still enjoy income effects of the garment sector if male members gained jobs or additional income, these effects are still likely smaller than those in families who gained an entirely new wage earner as a result of the garment industry expansion. Since families where mothers or sisters worked outside the home may differ in other unobservable ways from families where mothers or sisters did not, these results should not be interpreted as heterogeneous effects of the garment industry based on exogenous variation in mother's or sister's 
labor force participation. Instead, our goal is only to identify a subsample unlikely to be driven by wealth or time allocation effects.

Table 6 provides these results. The effects of the garment industry are actually larger in households where the mother or older sister did not work. ${ }^{14}$ This suggests that the education effects are driven by either changing returns to skill, or through the overall increases in female bargaining power documented in Majlesi (2014). While we cannot separate those channels, the combined effect of the two is still an important policy parameter, since it represents the effects of a new industry that expands women and girls' opportunity sets.

We next examine whether the effects of exposure to garment jobs on schooling decisions varies by a girl's age. To do this, we use the complete school enrollment history for each child to estimate how factory presence affects a child's propensity to stay enrolled in school during each year of her schooling life-cycle. The first column of Table 7 shows that a girl is 7.2 percentage points more likely to be in school (relative to her brother) in the years when factories were active close to the village. The estimates also imply that a girl in a garment-proximate village is 4.4 percentage points more likely to be in school compared to a girl living in a control village in the same subdistrict. These effects are substantial relative to a mean enrollment probability of $42 \%$ across all ages and years in the sample.

Column 2 allows the effect of the garment industry on enrollment to vary by the child's age. The marginal effects of the garment industry on girl's enrollment from the coefficients estimated in this regression are shown in figure 5. The marginal effects are decreasing in age: they are positive and significant for girls age 9 and under. For instance, a 6 -year-old girl in a village with access to garment jobs has a 7.6 percentage point increased probability of enrollment than a 6 -year-old girl in

\footnotetext{
${ }^{14}$ One explanation for this effect is that negative time allocation effects (girls who fill in at home for a mother or older sister in the garment industry) are bigger in magnitude than income effects.
} 
a village without factories nearby. The marginal effects actually turn slightly negative for the oldest girls (aged 17 and 18), suggesting a drop-out motive (Atkin 2012), where 17-18 year olds drop out to go work in factories.

\subsection{The Effects of the Garment Industry on Female Labor Force Participation}

Given this hint of drop-outs, we next turn to a more direct channel through which the garment industry could prompt girls to delay marriage and childbearing: their labor force participation decisions. Table 8 provides difference in difference results of the effects of easier access to garment factories on the probability that a girl has ever worked outside of the home. In column 1, we see that girls in garment-proximate villages are 15 percentage points more likely to have ever worked outside the home than girls in control villages. Column 2 shows that these effects are strongest amongst girls for whom factory presence coincided with the stage of their life-cycle where they are most likely to enter the labor force (ages 10 to 29). These girls are 12 percentage points more likely to have worked than girls of similar ages in control villages. In column 3 , we consider the age cutoff corresponding to the ages at which girls are at greatest risk for marriage in Bangladesh; ages 10 and 23 are the $10^{\text {th }}$ and $90^{\text {th }}$ percentiles of age at marriage in our sample. Girls that enjoyed factory exposure during that critical period are 13 percentage points more likely to work outside the home than girls of the same age in control villages. This hints at the possibility that working in garment factories is a potential reason why girls in garment-proximate villages choose to delay marriage and childbirth relative to their counterparts in control villages.

\subsection{The Effects of the Female Stipend Program (FSP) on School Enrollment, Marriage, and Childbearing}

Having documented the effects of the garment industry expansion on girls' marriage, childbearing, and education, we now benchmark the magnitudes of those impacts against a large- 
scale education promotion policy for Bangladeshi girls: the government's "female school stipend program" (FSP). This program has been widely credited with narrowing and then over-turning the gender gap in education in Bangladesh, and leading to delayed marriage and childbearing, and it is therefore valuable to investigate how the garment industry effect on girls' enrollment compares to that of the FSP.

We identify effects of the FSP by taking advantage of the fact that it was implemented in 1994, but only for girls in $6^{\text {th }}$ grade and above. Accordingly we identify the FSP effects on enrollment through a triple difference: Do FSP-eligible girls become more likely to stay enrolled after 1994 than boys in grades 6 and above, allowing for gender-specific differential enrollment effects post 1994 ? While the Post $1994 \times$ Female term allows for effects on younger girls, who stay in school in anticipation of the program, and the Post $1994 \times$ In school 6 years allows for spillovers effects on the male classmates of the girls receiving the subsidy, a caveat of this strategy is that it assumes younger brothers are not affected by the subsidy. To the extent that their enrollment is either boosted (if, say, the older girl can now accompany them to school) or lowered (if the family diverts resources from older girls to younger boys), the FSP result we report may not be based on exactly the right counter-factual. We nonetheless think that it is a useful benchmark, even in light of this caution.

Table 9 shows these results. We find no evidence that girls who had been in school for at least 6 years were more likely to remain in school after 1994 and in fact, the point estimate on the triple interaction Post $1994 \times$ Female $\times$ In school 6 years interaction is negative. Column 2 shows that including controls for the garment industry does not affect this conclusion.

Table 10 estimates the effects of the FSP on girl's marriage and childbearing. Since we can no longer use boys as a control group, we use a double-difference strategy that estimates whether 
the hazard of marriage or childbearing decreases in 1994 for girls who has been in school for 6 years, relative to girls who had not. There is no evidence of this pattern; the coefficient on Post $1994 \times$ In school 6 years is very close to zero in both the marriage and the childbearing regressions. While the inability to use boys as a control group introduces a further caveat - younger girls may anticipate the subsidy - we nonetheless again think that the effects are interesting even in light of this caveat. Including controls for the garment industry does not change the conclusion; meanwhile the effects of the garment industry on girls' schooling remaining positive and significant.

In summary, not only do we find that manufacturing growth in Bangladesh resulted in significant changes to young girls' schooling, work, marriage, and fertility decisions, the data indicate that the garment industry is the more likely explanation for the reduced gender gap in schooling in Bangladesh, rather than the prominent cash transfer program to which policymakers have been quick to attribute that credit. ${ }^{15}$ Even data in its simplest form (the time series graphs of age at marriage, fertility, and boys' and girls' enrollment in Figure 1) suggest that the these changes began in Bangladesh started before the FSP program was instituted, and that differential trend simply continued after FSP. While we do not wish to deny that conditional cash transfers have had large and important impacts on girls elsewhere in the world, ${ }^{16}$ we only seek to argue broadly that careful evaluations of such programs are needed to separate the effects of these programs from other

\footnotetext{
${ }^{15}$ For instance, International Development Association (2009) posted a write-up on its website entitled "Stipends Triple Girls Access to School", in which all of the increase in girls' enrollment between 1991 and 2005 was attributed to the stipend. Since it did not have the data to estimate the counterfactual rise in girls' enrollment absent the program, it was not able to substantiate the claimed effect size. A World Bank internal report writes "There is no systematic evaluation that shows the causal effect of the program on increased enrolment of girls in schools, yet nothing else can explain the exponential increase in gender parity." See also Raynor and Wesson (2006) for a review of other potential effects attributed to the FSP.

16 The negligible effects of the FSP that we estimate may be due to its small transfer size (the current monthly stipend ranges from $\$ 0.64$ US to $6^{\text {th }}$ graders to $\$ 1.50$ US to $10^{\text {th }}$ graders); other conditional cash transfer programs around the world offer transfers that are a much larger percentage of the income of the median receipt household.
} 
simultaneous factors, especially in environments like Bangladesh that have had such dramatic increase in job opportunities for women.

\section{Conclusion}

This paper has studied the effects of new employment opportunities in the ready-made garment industry on women's schooling, work, marriage and fertility decisions in a poor country. We find that manufacturing sector growth in Bangladesh had sizeable effects on parents' propensity to keep younger girls in school, older girls' propensity to engage in wage work, and both of these factors allowed women to postpone marriage and childbirth. The garment industry has likely played a key role in the remarkable progress Bangladesh has made in improving women's lives over the past 40 years. Fertility has dropped from 5.9 children per woman in 1983 to 2.3 births per woman in 2009 (World Development Indicators), and woman's average age at marriage has risen from 14.6 for marriages between 1980 and 1985 to 17.0 for marriages between 2005 and 2009 (Demographic and Health Survey).

Moreover, Bangladesh attained gender parity in school enrollment fifteen years before the Millennium Development Goals deadline for achieving this outcome. We now conduct an approximate back-of-the-envelope calculation to infer how much of the gains in girls' enrollment nationwide can be attributed to the remarkable rise in garment exports. We multiply the actual growth in garment exposure between 1983 and 2009 by the marginal effect of exposure to the garment on enrollment estimated in our regression model, and find that in villages within commuting distance to garment factories, exposure to these jobs led to a 38.6 percentage point increase in school enrollment rates. ${ }^{18}$ Using our earlier back-of-the envelope calculation that $15 \%$ of

\footnotetext{
${ }^{18}$ Specifically, column 1 of table 6 indicates that an additional year of exposure to the garment industry increases the probability a girl is enrolled in school by 0.0722 . On average the sample was exposed for $38.2 \%$ of the sample period for
} 
women between the ages of 16 and 30 across the country work in the garment sector (versus $39 \%$ in our sample of garment-proximate villages), proportionally extrapolating from our estimates suggests that roughly 14.8 percentage points of the national gain in girls' enrollment could be attributed to the growth in this export industry. While there are some important caveats to these results - they assume that the estimated coefficients would apply to other areas of the country - they nonetheless suggest that the garment industry was an important source of nationwide school enrollment growth.

Taken together, our results suggest that education policy in developing countries is closely tied to trade policy or industrial policy, and enrollments strongly respond to the arrival of jobs, especially if these jobs reward education. The manufacturing growth also improves welfare for young women, as they are able to avoid early marriage and childbirth, which have adverse intergenerational consequences.

years after 1983, and there are 14 years of observations per child (during years they were between the ages 5 of 18), so on average enrollment went up by $0.0772 \times .382 \times 14=38.6 \%$. This effect appears large relative to other educationfocused interventions around the world, Mexico's Progresa program (which provided three years of monthly cash grants equivalent to one-fourth of average family income conditional on child school attendance) increased enrollment by 3.43.6 percentage points for all students (Kremer and Holla 2009). In Kenya, providing free school uniforms to sixth grade pupils increased the enrollment rate by 2 percentage points for boys, and by 2.5 percentage points for girls. 


\section{Appendix: Construction of sample and variables used in the analysis}

We began by randomly sampling 60 villages in 4 subdistricts in Dhaka and Gazipur districts in Bangladesh (Savar and Dhamrai in Dhaka District; Gazipur Sadar and Kaliakur in Gazipur district). We stratified by whether the villages were considered by a BGMEA official to be within commuting distance of a garment factory (at the time of the survey, summer 2009) and then chose 44 garment-proximate villages and 16 control villages not within commuting distance to garment factories.

For each selected village, we conducted a census that provided a sampling frame of all households in the villages and also identified whether the households contained a garment worker. We then selected a random sample of households from each selected village, sampling more households from the larger villages (exact stratification available from authors upon request). We oversampled households with current garment workers (and also, for use in other projects, households with a consanguineous marriage or a female born between 1975 and 1980).

The retrospective schooling, marriage, and childbirth information is taken from the module administered to the female household head. This information was collected about all of her offspring, whether or not they still reside in the home. Information about the work history of female offspring not in the household was in the module administered to the male head; this information is merged with information from the household roster on resident daughters to create a dataset of work history of all female offspring.

Below we provide more information on the construction of the variables used in the empirical analysis:

\section{Variable}

Married

\section{Definition}

A binary variable equal to one if an individual was married in year t; and equal zero in every year that he/she remained unmarried 
A binary variable equal to one if an individual first gave birth in year $\mathrm{t}$ (or first FirstBirth became a father, for males); and equal to zero in every year that he/she has not yet become a parent

$\begin{array}{ll}\text { GarmentVillage } & \text { A binary variable equal to one if the BGMEA official considered the villas } \\ \text { be within commuting distance of garment factories and zero otherwise }\end{array}$

A continuous variable that gives the number of years of a certain critical period (from birth to the time of marriage/first birth, or from 5 to 18 for the

YearsExposure education regressions) during which anyone from the village in which an individual grew up (as defined by the place of residence of his/her parents) had been working in the garment industry

Education

A continuous variable giving completed years of education

A binary variable equal to one if the individual was enrolled in school in a given

Enroll year (constructed using retrospective information about the age the individual began school and ultimate completion), and zero if the individual was not enrolled in school. It is defined from ages 5 to 18.

A binary variable equal to one if any from the village in which an individual

PostGarments grew up (as defined by the place of residence of his/her parents) had begun working in the garment industry by that year

EverWorked

A binary variable equal to one if a someone has ever worked outside the home; zero otherwise; we only have information for females

A binary variable equal to one if anyone from the village in which an individual

AnyExposure grew up has been working in the garment industry during a certain critical period

Bibliography

Afsar, R. 1998. "Working and Living Conditions of the Garment Factory Workers in Bangladesh and Health Hazards with Special Focus on the Threat of STDs/AIDS/HIV: A Case Study on the Role of NGO Interventions." .

Amin, S., I. Diamond, R. T. Naved, and M. Newby. 1998. "Transition to Adulthood of Female Garment-Factory Workers in Bangladesh." Studies in Family Planning 29 (2): 185-200.

Ashcraft, A., K. Lang, and I. Fernández-Val. 2013. "The Consequences of Teenage Childbearing: Consistent Estimates when Abortion Makes Miscarriage Nonrandom." Economic Journal 123 (571): 875-905.

Atkin, D. 2012. "Endogenous Skill Acquisition and Export Manufacturing in Mexico." Unpublished manuscript. 
_.2009. "Working for the Future: Female Factory Work and Child Health in Mexico." Unpublished Manuscript, Yale University.

Badiani, R. 2009. "Factories and Farms: How does Economic Growth Impact Rural Incomes and Education?"Yale University.

Banerjee, A., S. Cole, E. Duflo, and L. Linden. 2007. "Remedying Education: Evidence from Two Randomized Experiments in India." The Quarterly Journal of Economics 122 (3): 1235-1264.

Bangladesh Bureau of Statistics. 2010. "Foreign Trade Statistics of Bangladesh: 2008-09.".

Bangladesh Export Processing Bureau. 2009. "Annual Report on the Ready-made Garment Industry.".

Bangladesh Garment Manufacturers and Exporters Association (BGMEA). 2013. "Ready-made Garment Yearbook.".

Brambilla, I., G. Porto, and A. Tarozzi. 2012. "Adjusting to Trade Policy: Evidence from US Antidumping Duties on Vietnamese Catfish." Review of Economics and Statistics 94 (1): 304-319.

Burde, D., and L. Linden. 2013. "The Effect of Proximity on School Enrollment: Evidence from a Randomized Controlled Trial in Afghanistan." American Economic Journal: Applied Economics 5 (3): 27-40.

Chaaban, J. and W. Cunningham. 2011. "Measuring the Economic Gain of Investing in Girls: The Girl Effect Dividend." Policy Research Working Paper 5753.

Dinkelman, T., and C. A. Martinez. 2014. "Investing in Schooling in Chile: The Role of Information about Financial Aid for Higher Education." Review of Economics and Statistics 96 (2): 244-257.

Duflo, E., P. Dupas, and M. Kremer. 2011. "Peer Effects, Teacher Incentives, and the Impact of Tracking: Evidence from a Randomized Evaluation in Kenya." American Economic Review 101 (5): 1739-1774.

Duflo, E., R. Hanna, and S. Ryan. 2012. "Incentives Work: Getting Teachers to Come to School." American Economic Review 102 (4): 1241-1278.

Federman, M., and D. I. Levine. 2005. "The Effects of Industrialization on Education and Youth Labor in Indonesia." Contributions to Macroeconomics 5 (1): 1-32.

Field, E., and A. Ambrus. 2008. "Early Marriage, Age of Menarche, and Female Schooling Attainment in Bangladesh." Journal of Political Economy 116 (5): 881-930.

Fletcher, J., and B. Wolfe. 2009. "Education and Labor Market Consequences of Teenage Childbearing: Evidence using the Timing of Pregnancy Outcomes and Community Fixed Effects." The Journal of Human Resources 44 (2): 303-325.

Foster, A., and M. R. Rosenzweig. 1996. "Technical Change and Human-Capital Returns and Investments: Evidence from the Green Revolution." American Economic Review 86 (4): 931-953.

Geronimus, A., and S. Korenman. 1992. "The Socioeconomic Consequences of Teen Childbearing Reconsidered." The Quarterly Journal of Economics 107 (November): 1187-1214.

Gibbs, N. 2011. "The Best Investment." Time, 64. 
Girl Up. 2011. "Girl Up Highlights the Importance of Counting Girls as World Population Grows to 7 Billion." Press release.

Glewwe, P., M. Kremer, and S. Moulin. 2009. "Many Children Left Behind? Textbooks and Test Scores in Kenya." American Economic Journal: Applied Economics 1 (1): 112-135.

Glewwe, P., M. Kremer, S. Moulin, and E. Zitzewitz. 2004. "Retrospective Vs. Prospective Analyses of School Inputs: The Case of Flip Charts in Kenya." Journal of Development Economics 74 (1): 251-268.

Heath, R. 2011. "Why do Firms Hire using Referrals? Evidence from Bangladeshi Garment Factories."Yale University.

Helper, S. R., D. I. Levine, and C. Woodruff. 2006. "How does Economic Liberalization Affect Investment in Education? Evidence from Mexico."UCSD, .

Hotz, V. J., S. McElroy, and S. Sanders. 2005. "Teenage Childbearing and its Life Cycle Consequences: Exploiting a Natural Experiment." The Journal of Human Resources 40 (3): 683-715.

International Development Association. "IDA at Work: Bangladesh: Stipends Triple Girls' Access to School."2011, http://web.worldbank.org/WBSITE/EXTERNAL/EXTABOUTUS/IDA/0,,contentMDK:21227882 me nuPK:3266877 pagePK:51236175 piPK:437394 theSitePK:73154,00.html.

Jensen, R. 2010. "The (Perceived) Returns to Education and the Demand for Schooling." Quarterly Journal of Economics 125 (2): 515-548.

_. 2012. "Do Labor Market Opportunities Affect Young Women's Work and Family Decisions? Experimental Evidence from India." Quarterly Journal of Economics 127 (2): 753-792.

Jensen, R., and R. Thornton. 2003. "Early Female Marriage in the Developing World." Gender \& Development 11 (2): 9-19.

Kabeer, N., and S. Mahmud. 2004. "Globalization, Gender and Poverty: Bangladeshi Women Workers in Export and Local Markets." Journal of International Development 16: 93-109.

Khatun, F., M. Rahman, D. Bhattacharya, K. G. Moazzem, and A. Shahrin. 2007. "Gender and Trade Liberalization in Bangladesh: The Case of Ready-made Garments.".

Kremer, M., and A. Holla. 2009. "Improving Education in the Developing World: What have we Learned from Randomized Evaluations?" Annual Review of Economics 1: 513-542.

Le Brun, A., S. R. Helper, and D. I. Levine. 2011. "The Effect of Industrialization on Children's Education. the Experience of Mexico." Review of Economics and Institutions 2 (2): 2-34.

Levine, R., C. B. Lloyd, M. Greene, and C. Grown. 2009. "Girls Count: A Global Investment and Action Agenda." .

Majlesi, K. 2014. "Labor Market Opportunities and Women's Decision Making Power within Households." Unpublished Manuscript.

Mammen, K., and C. Paxson. 2000. "Women's Work and Economic Development." The Journal of Economic Perspectives: 141-164. 
McKinsey \& Company. 2011. "Bangladesh's Ready-made Garments Landscape: The Challenge of Growth." Apparel, Fashion \& Luxury Practice.

Mobarak, A. M., R. Kuhn, and C. Peters. 2013. "Consanguinity and Other Marriage Market Effects of a Wealth Shock in Bangladesh." Demography 50 (5): 1845-1871.

Mostafa, R. and S. Klepper. 2009. "Industrial Development through Tacit Knowledg Seeding: Evidence from the Bangladesh Garment Industry." Unpublished manuscript.

Munshi, K., and M. R. Rosenzweig. 2006. "Traditional Institutions Meet the Modern World: Caste, Gender, and Schooling Choice in a Globalizing Economy." The American Economic Review 96 (4): 1225-1252.

Muralidharan, K., and V. Sundararaman. 2011. "Teacher Performance Pay: Experimental Evidence from India." Journal of Political Economy 119 (1): 39-77.

New York Times. 2013. "Worker Safety in Bangladesh and Beyond." The New York Times.

Nguyen, T. 2008. "Information, Role Models and Perceived Returns to Education: Experimental Evidence from Madagascar." Unpublished manuscript.

Oster, E., and B. M. Steinberg. 2013. "Do IT Centers Promote School Enrollment? Evidence from India." Journal of Development Economics 104: 123-135.

Paul-Majumder, P. and A. Begum. 2006. Engendering Garment Industry: The Bangladesh Context The University Press Limited.

Pitt, M. M., M. R. Rosenzweig, and N. Hassan. 2012. "Human Capital Investment and the Gender Division of Labor in a Brawn-Based Economy." American Economic Review 102 (7): 3531-3560.

PRI/BBC. "US Ends Trade Privileges to Bangladesh Following Garment Factory Disasters."2014, http://www.pri.org/stories/2013-06-28/us-ends-trade-privileges-bangladesh-following-garment-factorydisasters.

Raynor, J., and K. Wesson. 2006. "The Girls' Stipend Program in Bangladesh." Journal of Education for International Development 2 (2).

Ribar, D. C. 1994. "Teenage Fertility and High School Completion." The Review of Economics and Statistics 76 (3): 413424.

Shastry, G. K. 2011. "Human Capital Response to Globalization: Education and Information Technology in India." Journal of Human Resources 47 (2): 287-330.

Verhoogen, E. 2008. "Trade, Quality Upgrading and Wage Inequality in the Mexican Manufacturing Sector." Quarterly Journal of Economics 123 (2): 489-530.

World Bank. 2011a. "Girls' Education: A World Bank Priority.".

_ . . 2011b. "World Development Report 2012: Gender Equality and Development.".

Zohir, S. C. 2001. "Gender Balance in the EPZ: A Socio-Economic Study of Dhaka Export Processing Zone in Bangladesh.". 
Table 1: Summary Statistics of Individuals in 2009

\begin{tabular}{lccc}
\hline & \multicolumn{2}{c}{ Garment Villages } & \\
\cline { 2 - 3 } & Garment Workers & Non-Garment Workers & Non-Garment Villages \\
\hline Age & 26.004 & 24.687 & 26.646 \\
Female & 0.546 & 0.494 & 0.499 \\
Wage (Taka) $)^{(1)}$ & 3800.759 & 4929.739 & 4188.98 \\
Years of Experience ${ }^{(1)}$ & 3.237 & 6.991 & 8.634 \\
Years of Education & 5.977 & 4.086 & 3.188 \\
Mother's Years of Education & 1.491 & 2.322 & 1.622 \\
House has a Cement Floor & 0.79 & 0.64 & 0.252 \\
Married & 0.742 & 0.503 & 0.499 \\
Has a Child & 0.389 & 0.426 & 0.458 \\
N & 965 & 3306 & 1225 \\
\hline
\end{tabular}

${ }^{(1)}$ conditional on working. Sample includes all members of households in 2009 survey. 
Table 2: Differences in Garment vs. Non-Garment villages

\begin{tabular}{|c|c|c|c|c|c|}
\hline & $\begin{array}{c}\text { Garment } \\
\text { Villages }\end{array}$ & $\begin{array}{c}\text { Non-Garment } \\
\text { Villages }\end{array}$ & P-value for Diff. & $\mathrm{N}_{\text {garment }}$ & $\mathrm{N}_{\text {non-garment }}$ \\
\hline \multicolumn{6}{|l|}{ INDIVIDUAL LEVEL } \\
\hline Completed Education, Females 50+ & 0.824 & 0.537 & 0.232 & 176 & 80 \\
\hline Completed Education, Males 50+ & 3.486 & 1.943 & $0.002^{* * *}$ & 222 & 88 \\
\hline Age At Marriage, Females 50+ & 14.788 & 14.462 & 0.604 & 85 & 39 \\
\hline Age At First Birth, Females 50+ & 19.286 & 21.162 & $0.090^{*}$ & 84 & 37 \\
\hline \multicolumn{6}{|l|}{ VILLAGE LEVEL } \\
\hline Distance to Dhaka (Km) & 1.795 & 6.813 & $<0.001 * * *$ & 44 & 16 \\
\hline Distance to a Girls' Secondary School (Km) & 5.659 & 6.375 & 0.662 & 44 & 16 \\
\hline Distance to a Boys' Secondary School (Km) & 6.932 & 10 & 0.16 & 44 & 16 \\
\hline Male Agr. Wage (Peak Season, In Taka) & 27.559 & 27.997 & 0.802 & 44 & 16 \\
\hline Female Agr. Wage (Peak Season, In Taka) & 22.563 & 22.701 & 0.945 & 44 & 16 \\
\hline
\end{tabular}

*** $\mathrm{p}<0.01, * * \mathrm{p}<0.05, * \mathrm{p}<0.1$

Only individuals born in village included 
Table 3: Discrete-Time Hazard Models Estimating the Effects of the Garment Industry on Marriage and Childbearing

\begin{tabular}{|c|c|c|c|c|c|c|}
\hline \multirow[b]{2}{*}{ Dependent Variable } & \multicolumn{4}{|c|}{ Girls } & \multicolumn{2}{|c|}{ Boys } \\
\hline & Married & Married & First Birth & First Birth & Married & First Birth \\
\hline Garment village $\mathrm{X}$ years exposed & $\begin{array}{c}-0.000482^{* *} \\
{[0.000231]}\end{array}$ & $\begin{array}{c}-0.00012 \\
{[0.000128]}\end{array}$ & $\begin{array}{c}-0.000360 * * \\
{[0.000184]}\end{array}$ & $\begin{array}{c}1.23 \mathrm{E}-09 \\
{[2.59 \mathrm{e}-09]}\end{array}$ & $\begin{array}{c}0.00012 \\
{[7.33 \mathrm{e}-05]}\end{array}$ & $\begin{array}{c}7.89 \mathrm{E}-05 \\
{[5.05 \mathrm{e}-05]}\end{array}$ \\
\hline Garment village $\mathrm{X}$ years exposed $\mathrm{X}$ age & & $\begin{array}{c}-2.08 \mathrm{E}-06 \\
{[1.38 \mathrm{e}-05]}\end{array}$ & & $\begin{array}{l}-1.40 \mathrm{E}-10 \\
{[2.95 \mathrm{e}-10]}\end{array}$ & & \\
\hline Garment village $X$ years exposed $X$ age $^{2}$ & & $\begin{array}{c}3.62 \mathrm{E}-07 \\
{[3.83 \mathrm{e}-07]}\end{array}$ & & $\begin{array}{c}3.80 \mathrm{E}-12 \\
{[8.02 \mathrm{e}-12]}\end{array}$ & & \\
\hline Observations & 29,081 & 29,081 & 30,180 & 30,180 & 36,258 & 36,235 \\
\hline Mean dependent variable & 0.0111 & 0.0111 & 0.0080 & 0.0080 & 0.0071 & 0.0051 \\
\hline Mean years of garment exposure & 6.390 & 6.390 & 6.430 & 6.430 & 6.098 & 6.209 \\
\hline
\end{tabular}

The dependent variable equals 1 in the year in which an individual was married or had his/her first child. Individuals are in the sample from birth until either the time of marriage or first birth, or the time of the survey (if unmarried or have not yet given birth). Years of exposure counts the years up to marriage or first birth that an individual in the regression was exposed to the garment industry (i.e. people in the village in which the individual grew up have been working in the garment industry). It equals zero for all individuals not in garment villages. All regressions have year of birth trends for garment and non-garment villages, and a dummy for garment village. Standard errors in brackets, clustered at the level of the individual; ${ }^{* * *} \mathrm{p}<0.01,{ }^{* *} \mathrm{p}<0.05,{ }^{*} \mathrm{p}<0.1$ 
Table 4: Pre-Garment Industry Trends in Enrollment, Marriage and Time of First Birth

\begin{tabular}{lccc}
\hline Sample & All & Females & Females \\
Dependent Variable & Enrolled & Married & First Birth \\
\hline Garment village X years to garment industry & 0.00515 & & \\
& {$[0.00415]$} & & \\
Garment village X female X years to garment industry & 0.00295 & $6.84 \mathrm{E}-05$ & $2.51 \mathrm{E}-11$ \\
& {$[0.00461]$} & {$[5.86 \mathrm{e}-05]$} & {$[4.95 \mathrm{e}-10]$} \\
\hline Observations & 6,214 & 21,610 & 22,406 \\
Mean Dependent Variable & 0.412 & 0.016 & 0.011 \\
\hline
\end{tabular}

The sample in each regression is individuals in garment villages, in years before the first person from that village worked in a garment factory. Years to garment industry is calculated by subtracting the year in which people from that village first worked in a garment factory from the year of the observation. It equals zero for all individuals not in garment villages. Column 1 includes family fixed effects, female $\mathrm{X}$ year of birth dummies, and age trends by gender; standard errors in brackets are clustered at the level of the family. Columns 2 and 3 include year dummies and a quadratic in age; standard errors in brackets are clustered at the level of the individual. $* * * \mathrm{p}<0.01, * * \mathrm{p}<0.05, * \mathrm{p}<0.1$ 
Table 5: Effects of the Garment Industry on Educational Attainment

(Dependent Variable $=$ Years of Education)

\begin{tabular}{lccc}
\hline \multicolumn{1}{c}{ Sample } & All & $\begin{array}{c}\text { Born 1995 or } \\
\text { before }\end{array}$ & $\begin{array}{c}\text { Born 1990 or } \\
\text { before }\end{array}$ \\
\hline Garment village X years exposed & $0.2596^{* * *}$ & -0.1364 & $-0.1797^{*}$ \\
Garment village X years exposed X female & {$[0.0750]$} & {$[0.0844]$} & {$[0.0971]$} \\
& $0.2211^{* * *}$ & $0.1701^{* *}$ & 0.1430 \\
\hline Observations & {$[0.0759]$} & {$[0.0855]$} & {$[0.0945]$} \\
R-squared & 2,341 & 1,416 & 1,013 \\
Mean dependent variable & 0.220 & 0.100 & 0.141 \\
Mean years of garment exposure & 4.317 & 5.931 & 5.938 \\
\hline
\end{tabular}

Years exposed counts the years during which the individual was between age 5 and 18 during which people in the village in which the individual grew up have been working in the garment industry. It equals zero for all individuals not in garment villages. All regressions have sibling FE's, female X quadratic in year of birth, year of birth trends for garment and non-garment villages by gender, and garment village $\mathrm{X}$ female. Standard errors in brackets, clustered at the level of the family; ${ }^{* * *} \mathrm{p}<0.01,{ }^{* *} \mathrm{p}<0.05,{ }^{*} \mathrm{p}<0.1$ 
Table 6: Effects of the Garment Industry on Educational Attainment by Mother's and Sister's Work Status (Dependent Variable $=$ Years Of Education)

\begin{tabular}{|c|c|c|c|c|c|c|}
\hline Sample & Mom worked & $\begin{array}{l}\text { Mom did not } \\
\text { work }\end{array}$ & $\begin{array}{c}\text { Older sister } \\
\text { worked }\end{array}$ & $\begin{array}{l}\text { Older sister did } \\
\text { not work }\end{array}$ & $\begin{array}{c}\text { Either mom or } \\
\text { older sister } \\
\text { worked }\end{array}$ & $\begin{array}{c}\text { Neither mom } \\
\text { nor older sister } \\
\text { worked }\end{array}$ \\
\hline \multirow[t]{2}{*}{ Garment village $\mathrm{X}$ years exposed } & 0.1939 & $0.2183^{* * *}$ & 0.2419 & $0.2483 * * *$ & 0.2174 & $0.1706^{*}$ \\
\hline & {$[0.1484]$} & {$[0.0838]$} & {$[0.2224]$} & {$[0.0885]$} & {$[0.1327]$} & {$[0.1004]$} \\
\hline \multirow[t]{2}{*}{ Garment village $\mathrm{X}$ years exposed $\mathrm{X}$ female } & 0.1717 & $0.2839 * * *$ & -0.1409 & $0.3003 * * *$ & 0.1317 & $0.3504 * * *$ \\
\hline & {$[0.1428]$} & {$[0.0872]$} & {$[0.2498]$} & {$[0.0832]$} & {$[0.1316]$} & {$[0.0964]$} \\
\hline Observations & 705 & 1,610 & 392 & 1,949 & 942 & 1,373 \\
\hline R-squared & 0.433 & 0.171 & 0.284 & 0.215 & 0.353 & 0.178 \\
\hline Mean dependent variable & 3.133 & 4.816 & 4.219 & 4.337 & 3.601 & 4.786 \\
\hline Mean years of garment exposure & 10.088 & 5.247 & 8.809 & 6.347 & 9.497 & 4.816 \\
\hline
\end{tabular}

Years exposed counts the years during which the individual was between age 5 and 18 during which people in the village in which the individual grew up have been working in the garment industry. It equals zero for all individuals not in garment villages. All regressions have sibling FE's, a female-specific quadratic term for year of birth; year of birth trends for garment and non-garment villages by gender, and garment village X female. Standard errors in brackets, clustered at the level of the family; $* * * \mathrm{p}<0.01, * * \mathrm{p}<0.05, * \mathrm{p}<0.1$ 


\section{Table 7: Effects of the Garment Industry on School Enrollment (Dependent Variable $=1[$ Enrolled $])$}

\begin{tabular}{lcc}
\hline Garment village X post garments & -0.0278 & 0.066 \\
Garment village X post garments X female & {$[0.0327]$} & {$[0.0423]$} \\
& $0.0722^{*}$ & 0.0801 \\
Garment village X post garments X age & {$[0.0426]$} & {$[0.0512]$} \\
& & $-0.0153^{* * *}$ \\
Garment village X post garments X female X age & & {$[0.00404]$} \\
& & -0.00291 \\
Observations & & {$[0.00476]$} \\
R-squared & 23,129 & 23,129 \\
Mean dependent variable & 0.051 & 0.056 \\
Mean 1(post garment) & 0.421 & 0.421 \\
\hline
\end{tabular}

The dependent variable is a binary variable equal to 1 if the individual was enrolled in school in a certain year. Post garments is a binary variable equal to 1 if people in the village in which the individual grew up were working in the garment industry in a particular year. It equals zero for all individuals not in garment villages. Regressions include family fixed effects, garment village enrollment trends by gender, a dummy for female X garment village, female $\mathrm{X}$ year of birth dummies, and age trends by gender. Standard errors in brackets, clustered at the level of the family; ${ }^{* * *} \mathrm{p}<0.01$, ** $\mathrm{p}<0.05,{ }^{*} \mathrm{p}<0.1$ 
Table 8: Effects of the Garment Industry on Female Labor Force Participation

$($ Dependent Variable $=1[$ Ever Worked $])$

Garment village

$0.154 * * *$

$0.0650^{* *}$

0.0455

[0.0313]

[0.0315]

[0.0392]

Garment village X exposure between ages 10 to 29

$0.117 * *$

[0.0473]

Garment village X exposure between ages 30 to 49

[0.0751]

Garment village X exposure between ages 10 to 23

$0.127 * *$

[0.0537]

Garment village X exposure between ages 24 to 39

0.0677

[0.0587]

Observations

917

917

917

R-squared

0.161

0.164

0.171

Mean dependent variable

0.215

0.215

0.215

Exposure between ages $\mathrm{X}$ and $\mathrm{Y}$ is a binary variable that equals 1 if anyone in the village in which the individual grew up was been working in the garment industry when the individual was in a given age range. It equals zero for all individuals not in garment villages. Regressions include dummies for year of birth. Age 23 is the 90th percentile of age at marriage for women in the sample. Only females included. Standard errors in brackets, clustered at the level of the family; *** $\mathrm{p}<0.01,{ }^{* *} \mathrm{p}<0.05, * \mathrm{p}<0.1$ 
Table 9: Effects of the Female Stipend Program on School Enrollment (Dependent Variable $=1[$ Enrolled $])$

\begin{tabular}{lcc}
\hline Post 1994 X $\geq 6$ years of school & $-0.194 * * *$ & $-0.194 * * *$ \\
& {$[0.0461]$} & {$[0.0464]$} \\
$\geq 6$ years of school X female & -0.0156 & -0.016 \\
& {$[0.0607]$} & {$[0.0607]$} \\
Post 1994 X $\geq 6$ years of school X female & -0.0522 & -0.0519 \\
Garment village X post garments & {$[0.0672]$} & {$[0.0670]$} \\
& & -0.0138 \\
Garment village X post garments X female & & {$[0.0317]$} \\
& & 0.0408 \\
Observations & & {$[0.0372]$} \\
R-squared & 23,129 & 23,129 \\
Mean dependent variable & 0.058 & 0.058 \\
Mean FSP exposure & 0.421 & 0.421 \\
\hline
\end{tabular}

The triple interaction of post $1994 \mathrm{X} \geq 6$ years of school $\mathrm{X}$ female defines exposure to the FSP. Dependent variable is enrollment in year $t$. Regressions include family fixed effects and controls for year fixed effects interacted with a female dummy, garment village $\mathrm{X}$ female, age, female $\mathrm{X}$ age, and the main effect of 6 years of schooling. Standard errors in brackets, clustered at the level of the family; *** $\mathrm{p}<0.01,{ }^{* *} \mathrm{p}<0.05, * \mathrm{p}<0.1$ 
Table 10: Effects of the Female Stipend Program on Marriage and Childbearing

\begin{tabular}{lcccc}
\hline \multicolumn{1}{c}{ Dependent variable } & Married & First Birth & Married & First Birth \\
\hline Post 1994 X $\geq$ 6 years of school & 0.00107 & $1.91 \mathrm{E}-10$ & 0.00095 & $1.10 \mathrm{E}-10$ \\
Garment village X years exposed & {$[0.00132]$} & {$[3.20 \mathrm{e}-09]$} & {$[0.00125]$} & {$[2.91 \mathrm{e}-09]$} \\
& & & $-0.000546^{* * *}$ & $-0.000392^{* *}$ \\
& & & {$[0.000210]$} & {$[0.000169]$} \\
\hline Observations & 29,081 & 29,081 & 30,180 & 30,180 \\
Mean dependent variable & 0.0111 & 0.0111 & 0.0080 & 0.0080 \\
Mean FSP exposure & 0.1157 & 0.1259 & 0.1157 & 0.1259 \\
\hline
\end{tabular}

Only females included. In the female-only sample, the interaction of post $1994 \mathrm{X} \geq 6$ years of school defines exposure to the FSP. The dependent variable equals 1 in the year in which an individual was married or had his/her first child. Regressions include controls for age, age squared, dummies for year, and a dummy for garment village in columns 3 and 4 . Standard errors in brackets, clustered at the level of the individual; ${ }^{* *} \mathrm{p}<0.01,{ }^{* *} \mathrm{p}<0.05,{ }^{*} \mathrm{p}<0.1$ 
Figure 1: Enrollment, Female Marriage Age, and Fertility Trends in Bangladesh

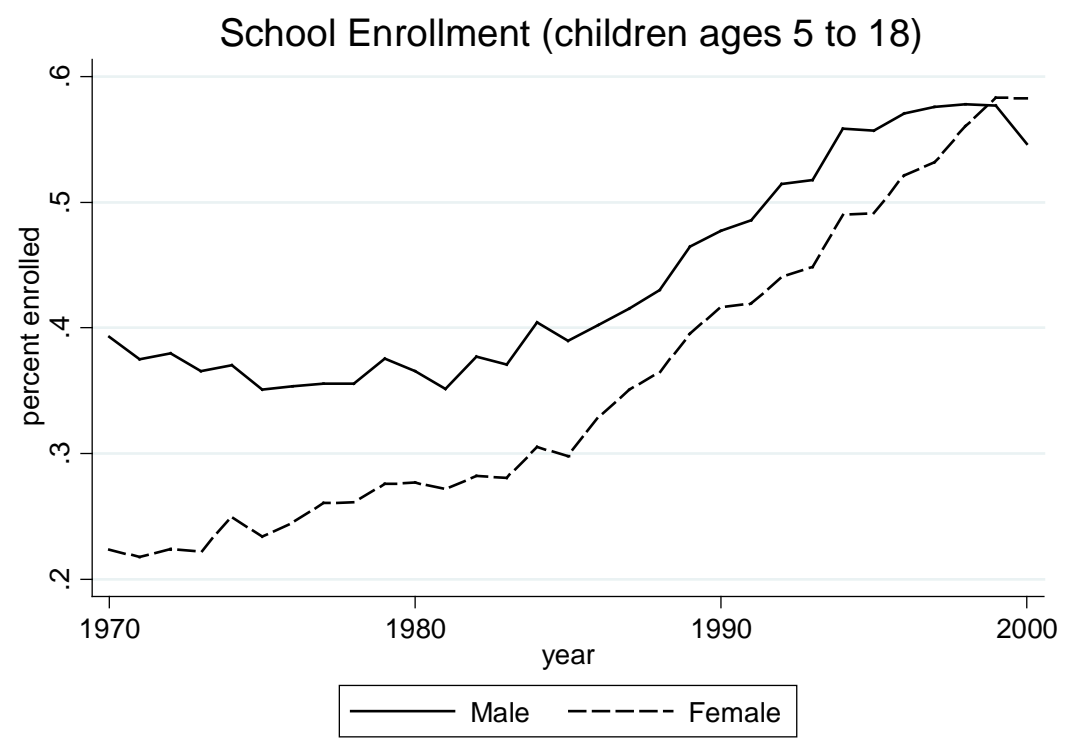

Source: Bangladesh Household Income and Expenditure Survey

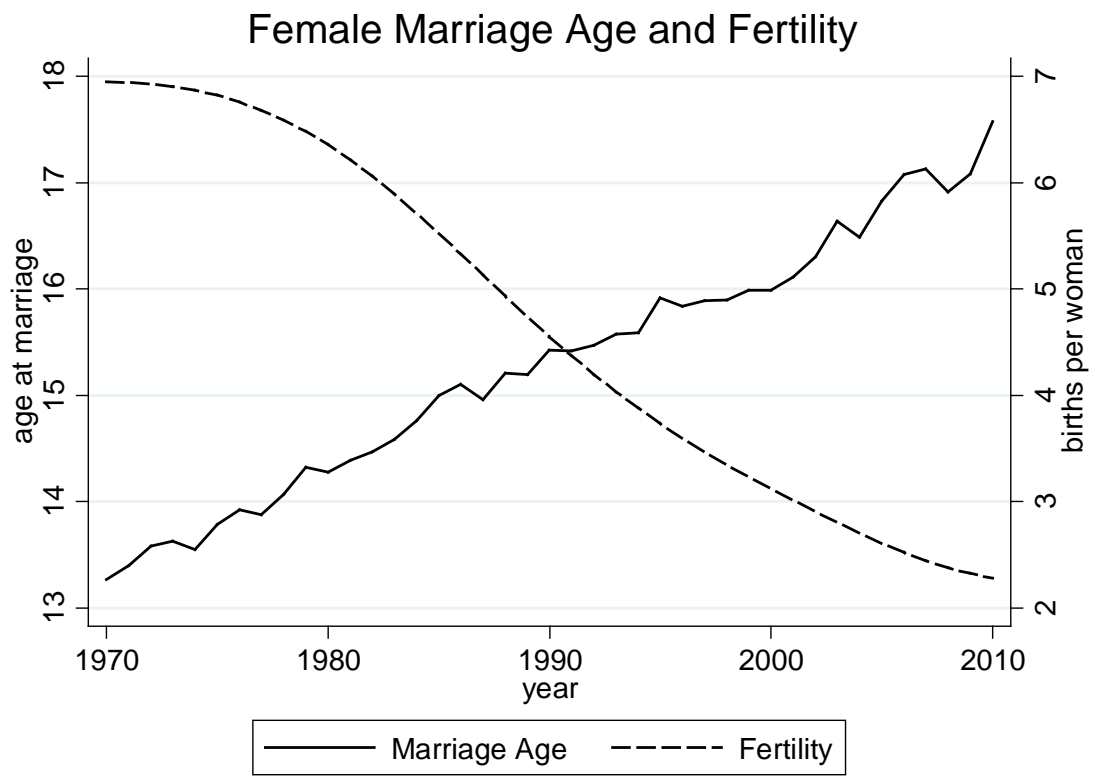

Source: World Bank Development Indicators (fertility), Demographic and Health Surveys (marriage age)

Note: Age at marriage is the average age of marriage of women entering their first marriage in the year given on the x-axis. Fertility is represents the number of children that would be born to a woman if she were to live to the end of her childbearing years and bear children in accordance with current age-specific fertility rates, as calculated by the World Bank for the World Development Indicators: http://data.worldbank.org/indicator/SP.DYN.TFRT.IN. 
Figure 2: Nation-wide Employment in the Garment Industry

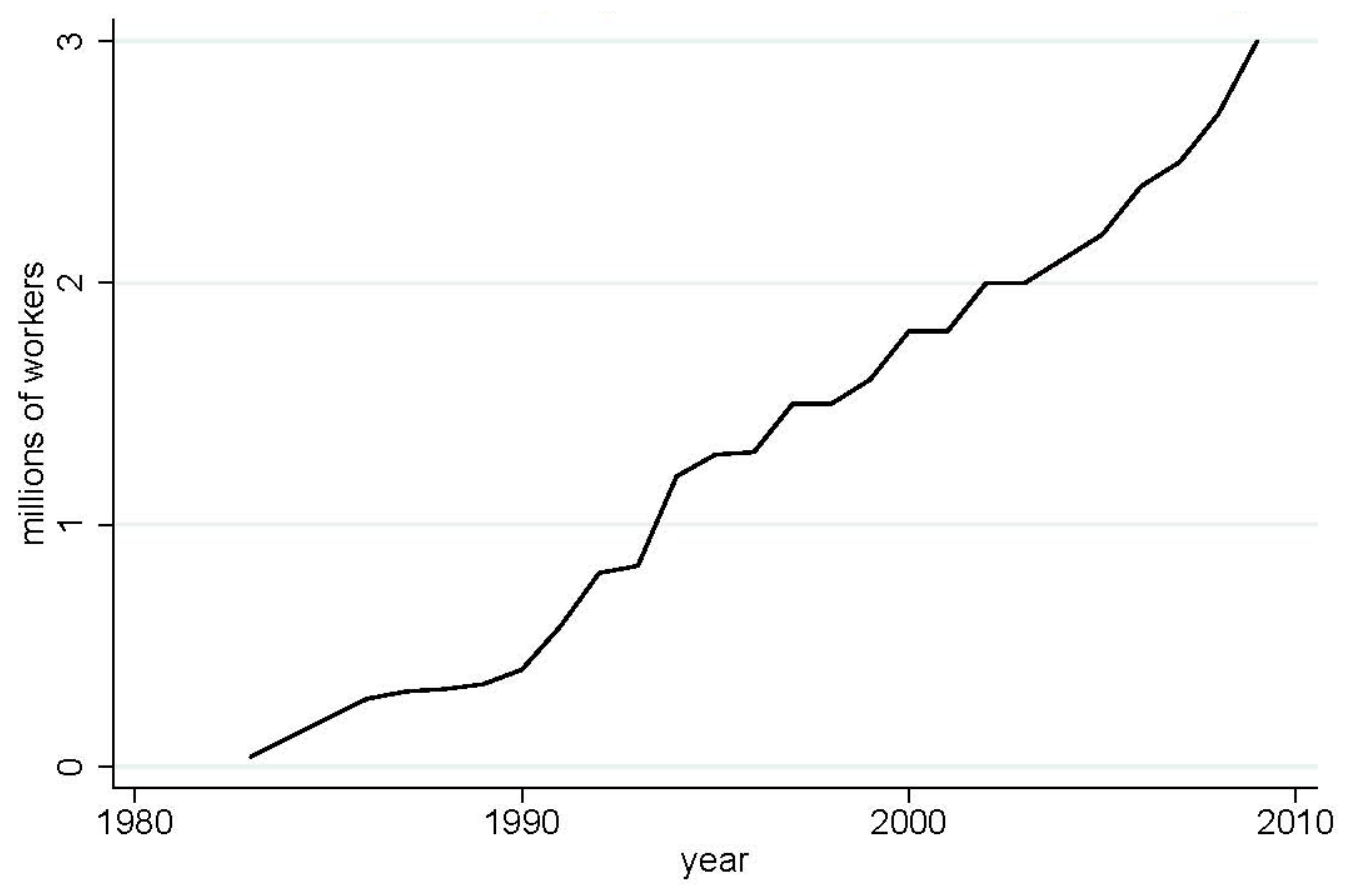

Source: Bangladesh Garments Manufacturers and Exporter Association (BGMEA) 
Figure 3: Characteristics of Sampled Female Garment Workers

Age and Education of Female Garment Workers
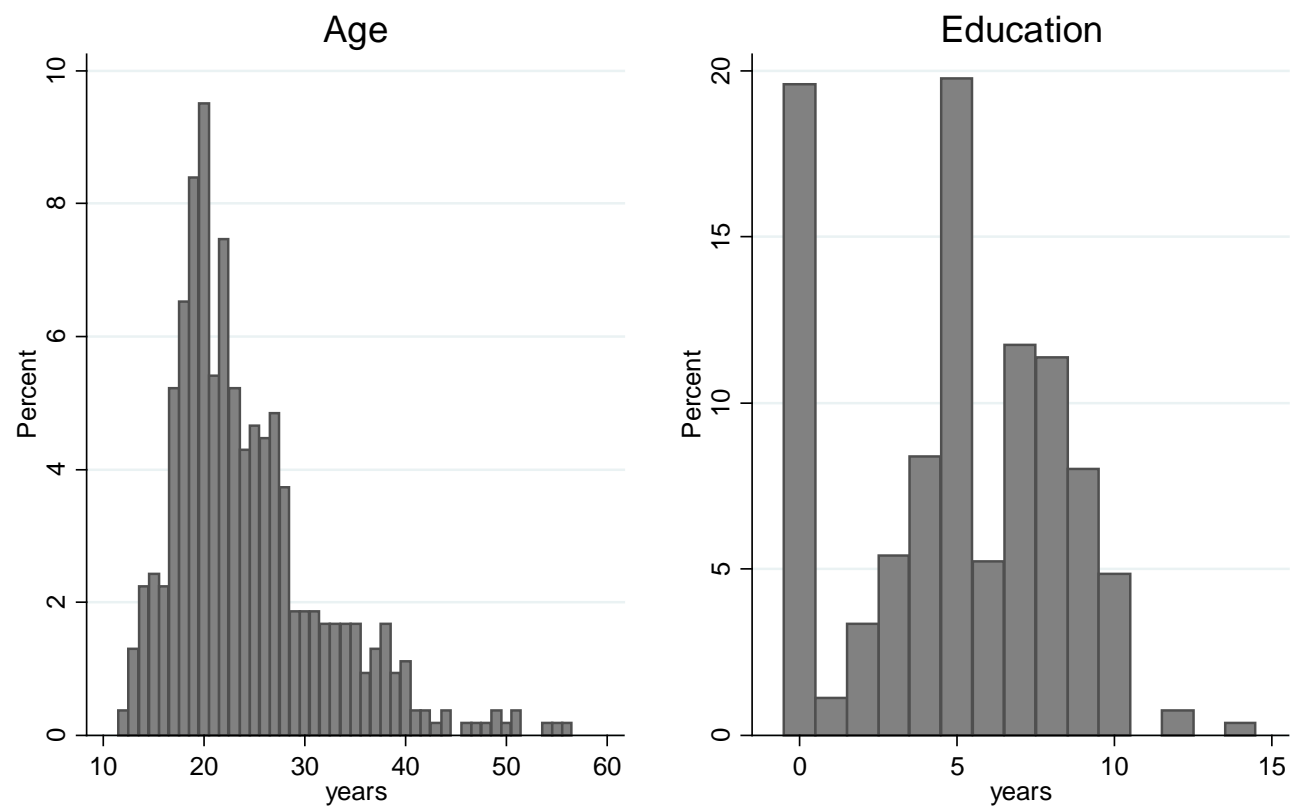

From 2009 survey of resident workers in Savar, Dhamrai, Gazipur Sadar and Kaliakur subdistricts 
Figure 4: Marginal Effects of the Garment Industry on Girls' Marriage and Childbearing by Age

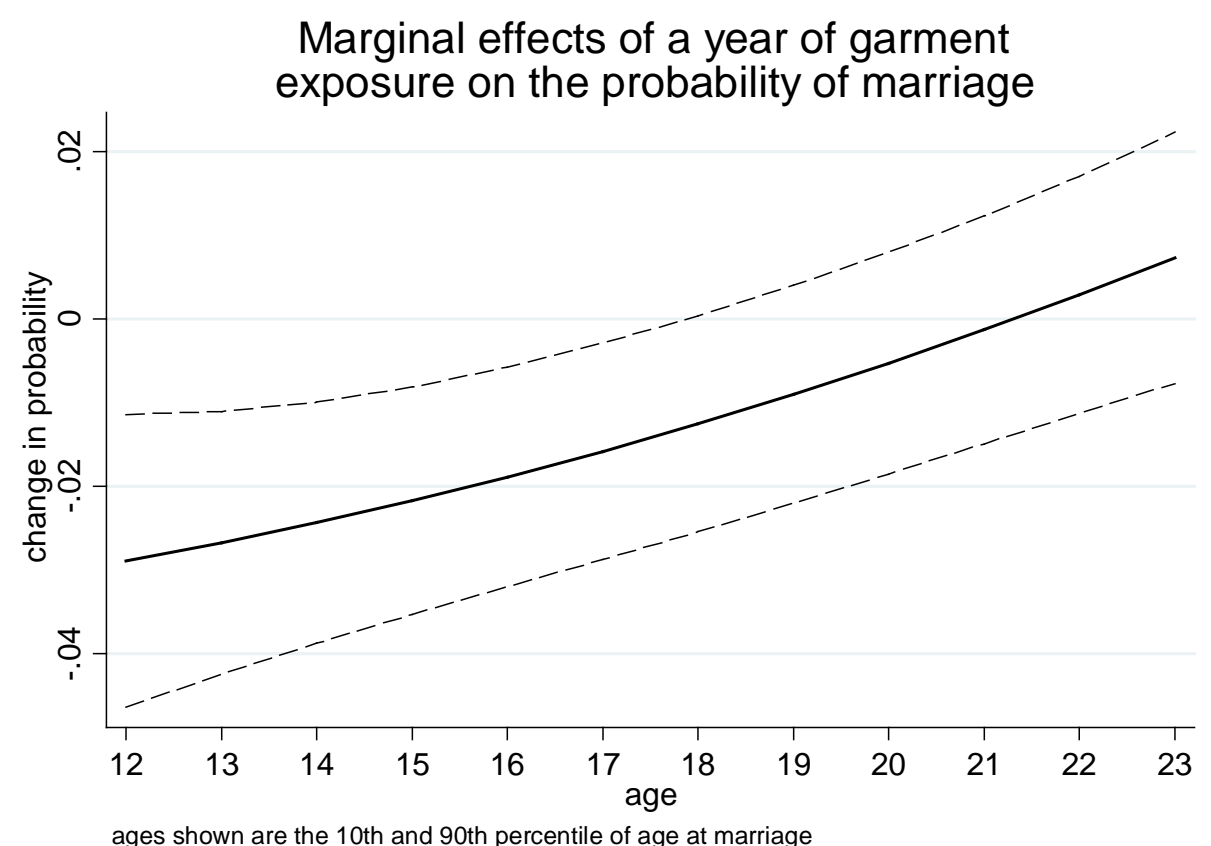

Note: Plots the marginal effect based on the regression results found in the second column of Table 3

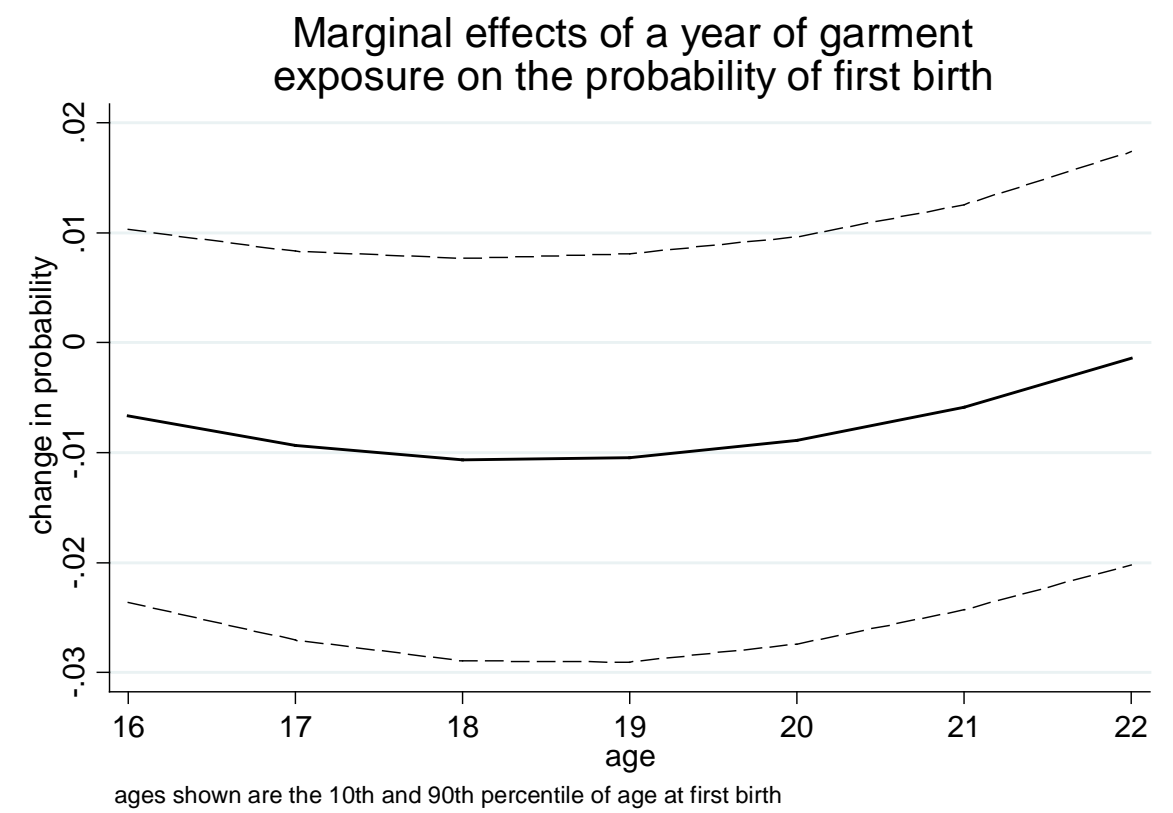

Note: Plots the marginal effect based on the regression results found in the fourth column of Table 3 
Figure 5: Marginal Effects of the Garment Industry on Girls' School Enrollment by Age

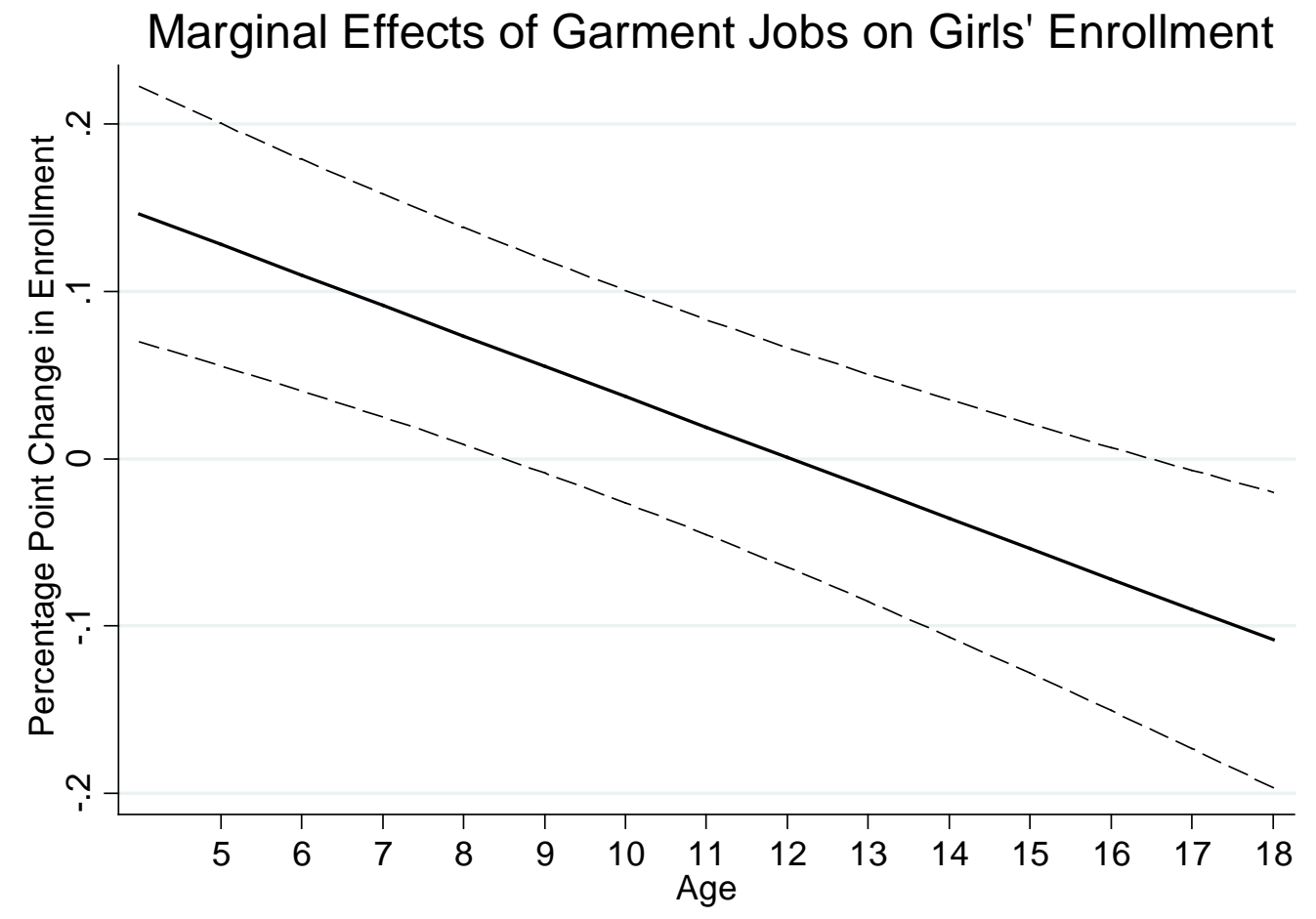

Note: Plots the marginal effect based on the regression results found in the second column of Table 7 